\title{
Pohybová a sportovní aktivita u dětí a mladistvých s kardiovaskulárním onemocněním
}

\author{
Doporučený postup České kardiologické společnosti a České společnosti tělovýchovného lékařství vypracovaný Pracovni skupinou \\ pediatrické kardiologie
}

Autorský kolektiv: Václav Chaloupecký', Oleg Reich', Jan Janoušek', Helena Bartáková', Jiří Radvanský, Kryštof Slabý2, Zuzana Urbanová3 ${ }^{3}$ Jan Škovránek

'Dětské kardiocentrum a Centrum výzkumu chorob srdce a cév, FN v Motole, Praha; ${ }^{2}$ Klinika rehabilitace a tělovýchovného lékařství 2. LF UK a FN v Motole, Praha; ${ }^{3}$ Klinika dětského a dorostového lékařství 1. LF UK a VFN, Praha

Adresa: Prof. MUDr. Václav Chaloupecký, CSc., Dětské kardiocentrum, FN v Motole, V Úvalu 84, 15006 Praha 5, e-mail:v.chaloupecky@fnmotol.cz

\section{úvod}

Možnost cvičit a sportovat má pro mladé jedince s kardiovaskulárním onemocněním mimořádný význam jak z hlediska fyzického vývoje, tak z hlediska psychosociálního zařazení. Cvičení nebo sport jsou nejlepší prevencí nežádoucí obezity, zvyšují sebevědomí a usnadňují sociální kontakt. Pohybovou aktivitu je nutno chápat v širokém kontextu životního stylu, který dítě získává zpočátku převážně podle rodinných vzorů. Přiměřená fyzická zátěž umožňuje dětem fyziologický rozvoj a má i velmi důležitou složku výchovnou. Pohybem a rekreační sportovní aktivitou dítě získává charakterové vlastnosti, jako je odvaha, sebevědomí a schopnost mezilidské komunikace. $Z$ tohoto pohledu je také zřejmé, že vrozené srdeční vady by měly být zkorigovány operací nebo intervenční katetrizací včas, aby se dítě mohlo co nejdříve zapojit do běžných sportovních aktivit.

Za určitých patologických stavů ale může nadměrná fyzická námaha ohrožovat jedince s kardiovaskulárním onemocněním zhoršením srdeční funkce, závažnými poruchami srdečního rytmu, synkopou, př́ípadně nejzávažnější komplikací - náhlým úmrtím. Při rozhodování, zda dítě může cvičit ve škole nebo sportovat, je také nutné zvážit rizika možných úrazů. Na druhé straně bylo v mnoha studiích u nemocných se srdečním selháním prokázáno, že kondiční cvičení a rekreační sport může funkci kardiovaskulárního systému zlepšit. ${ }^{1}$

Problematika posuzovaní funkční zdatnosti a rizika poruch srdečního rytmu u dětí a adolescentů s onemocněním srdce při pohybových aktivitách a sportu je komplexní a vyžaduje těsnou spolupráci praktických lékařů pro děti a dorost a tělovýchovných lékařu s ošetřujícím dětským kardiologem. Ve složitých případech jsou konzultována prríslušná centra.

Následující metodické pokyny vycházejí převážně z doporučení o způsobilosti jedinců s kardiovaskulárním onemocněním k závodnímu sportu podle American College of Cardiology Foundation (36. konference $\mathrm{v}$ Bethesdě) a Evropské kardiologické společnosti ${ }^{2-4}$ a dále $\mathrm{z}$ doporučení o způsobilosti k rekreačnímu sportu u geneticky podmíněných kardiovaskulárních onemocnění, která byla upravena podle zvyklostí pohybových a sportovních aktivit u dětí a mladistvých v České republice. ${ }^{5,6}$

\section{Terminologie a definice}

Doporučení z konference $\mathrm{v}$ Bethesdě se vyjadřují podle závažnosti kardiovaskulárního postižení $\mathrm{k}$ omezením pouze u závodních sportů. ${ }^{2}$ Závodní sport je zde definován 
jako organizovaná nebo individuální sportovní aktivita vyžadující pravidelný intenzivní trénink a pravidelnou účast na sportovních soutěžích, které kladou důraz na podání vynikajícího výkonu. Závodní sportovec má především silnou tendenci překonat sám sebe až na hranici fyzických možností, a to nezávisle na subjektivních obtížích. Rekreační sport charakterizuje různě intenzivní sportovní činnost s nepravidelným trénováním a bez sportovních soutěží kladoucích důraz na vítězství. $Z$ uvedeného je zřejmé, že za závodní sportování je rovněž nutno považovat různé sportovní soutěže organizované v rámci školní, př́padně univerzitní výuky.

Rozdělení závodních sportů podle typu a intenzity zátěže a s přihlédnutím k riziku úrazu nebo synkopy je shrnuto v tabulce 1. U zdravých osob dynamickou zátěž charakterizují rytmické změny svalové délky s relativně malým svalovým napětím. Srdeční frekvence, srdeční výdej, systolický tlak a spotřeba kyslíku se zvyšují, střední arteriální tlak mírnè stoupá, diastolický tlak a periferní cévní rezistence se snižují. Pro statickou zátěž jsou typické vysoké svalové napětí a výrazné zvýšení krevního tlaku. Spotřeba kyslíku, srdeční frekvence a srdeční výdej se zvyšují většinou jen mírně. Dynamická zátěž způsobuje objemové a statická zátěž tlakové systémové zatížení srdeční komory.

Rozdělení rekreačních sportů a pohybových aktivit podle stupně fyzické zátěže je uvedeno v tabulce 2, která je zkompilována podle doporučení Americké a Evropské

\begin{tabular}{|c|c|c|c|}
\hline Zátěž & $\begin{array}{l}\text { A } \\
\text { dynamická } \\
\text { nízká }\end{array}$ & $\begin{array}{l}\text { B } \\
\text { dynamická } \\
\text { střední }\end{array}$ & $\begin{array}{l}\text { C } \\
\text { dynamická } \\
\text { vysoká }\end{array}$ \\
\hline $\begin{array}{l}\text { III } \\
\text { statická } \\
\text { vysoká }\end{array}$ & 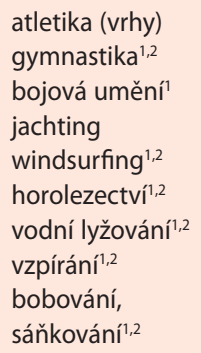 & $\begin{array}{l}\text { skateboarding } \\
\text { kulturistika }^{1,2} \\
\text { sjezdové lyžování1,2 } \\
\text { snowboarding }^{1,2}\end{array}$ & $\begin{array}{l}\text { cyklistika }^{1,2} \\
\text { kanoistika, } \\
\text { veslování } \\
\text { desetiboj } \\
\text { triatlon }^{1,2} \\
\text { rychlobrusleníl, }^{1,2} \\
\text { box }^{1}\end{array}$ \\
\hline $\begin{array}{l}\text { II } \\
\text { statická } \\
\text { střední }\end{array}$ & $\begin{array}{l}\text { jezdectví1,2 } \\
\text { potápění1,2 } \\
\text { lukostřelba } \\
\text { automobilové } \\
\text { a motocyklové } \\
\text { závody }{ }^{1,2}\end{array}$ & $\begin{array}{l}\text { atletika (skoky) }{ }^{1} \\
\text { běh (sprint) } \\
\text { krasobruslení }^{1} \\
\text { ragby }^{1}\end{array}$ & $\begin{array}{l}\text { košíková', } \\
\text { házená, lakros }{ }^{1} \\
\text { lední hokej } \\
\text { běžky (bruslení) } \\
\text { běh (střední } \\
\text { tratě) } \\
\text { plavání }\end{array}$ \\
\hline $\begin{array}{l}\text { I } \\
\text { statická } \\
\text { nízká }\end{array}$ & $\begin{array}{l}\text { biliár, kuželky } \\
\text { golf } \\
\text { střelba }\end{array}$ & $\begin{array}{l}\text { baseball, softball }{ }^{1} \\
\text { stolní tenis } \\
\text { volejbal } \\
\text { šerm }\end{array}$ & $\begin{array}{l}\text { kopaná1 } \\
\text { badminton, } \\
\text { tenis, squash } \\
\text { běžky (klasický } \\
\text { styl) } \\
\text { florbal' }^{1} \\
\text { chodectví } \\
\text { běh (dlouhé } \\
\text { tratě) }\end{array}$ \\
\hline
\end{tabular}

kardiologické společnosti pro jedince s geneticky podmíněnými kardiovaskulárními onemocněními ohroženými náhlým úmrtím. ${ }^{5,6}$

\section{Funkční vyšetření kardiovaskulárního systému}

Doporučení k pohybové aktivitě a sportu u dětí a mladistvých s kardiovaskulárními onemocněními vychází vždy z výsledků podrobného kardiologického vyšetření. Funkční posouzení kardiovaskulárního systému u komplexních vrozených srdečních vad má svá úskalí vyplývající ze značné individuální variability významnosti vady, způsobu operační nebo katetrizační léčby a prrítomnosti prrípadných reziduálních nálezů nebo nežádoucích následků léčby.

Velmi důležitá je anamnéza s cílenými dotazy na předchozí diagnostické a léčebné zákroky, fyzickou zdatnost a zejména na výskyt poruch srdečního rytmu a synkop, a to nejen u vyšetřovaného jedince, ale také u nejbližších příbuzných. Důležitá je znalost životního stylu dítěte a jeho rodiny $\mathrm{z}$ hlediska pohybových a sportovních aktivit.

K základnímu kardiologickému vyšetření patří kromě standardního EKG podrobné echokardiografické vyšetření. Důležité je správné měření a hodnocení krevního tlaku podle norem vztažených $\mathrm{k}$ věku, výšce a pohlaví. ${ }^{7}$ Při posuzování způsobilosti jedinců se závažnějšími kardiovaskulárními onemocněními $\mathrm{k}$ závodním a rekreačním sportům provádíme Holterovu monitoraci EKG a zátěžové vyšetření k vyloučení závažných poruch srdečního rytmu, snížené koronární rezervy nebo hypertenzní reakce. Opakovaná kardiologická vyšetření jsou i u méně významných kardiovaskulárních onemocnění, zejména při posuzování závodních sportovních aktivit, nezbytná. Nálezy se mohou časem zlepšit, ale také zhoršit.

\section{Doporučení pro pohybovou a sportovní aktivitu}

Doporučení pro pohybovou a sportovní aktivitu pro nejčastější vrozené srdeční vady jsou shrnuta $\mathrm{v}$ tabulce 3, pro získaná a hereditární srdeční onemocnění v tabulce 4 a pro poruchy srdečního rytmu v tabulce 5. Podle vý-

Tab. 2 Míra fyzické zátěže při rekreačních sportovních a pohybových aktivitách

\begin{tabular}{lll}
\hline Nízká & Střední & Vysoká \\
\hline biliár, bowling & baseball/softball & kopaná \\
golf & tenis (čtyřhra) & košíková \\
bruslení & jogging & kulturistika \\
jízda na koni & plavání & lední hokej \\
rychlá chůze & jachting & squash, florball \\
turistika s mírnější & turistika se střední zátěží & horolezectví \\
zátěží & cyklistika & atletika \\
spinning s mírnější & & sjezdové lyžování \\
zátěží & & běžky \\
& & tenis (dvojhra) \\
& & windsurfing \\
\hline Upraveno podle doporučeni Americké a Evropské kardiologické společnosti. ${ }^{5,6}$
\end{tabular}


Tab. 3 Vrozené srdeční vady

\begin{tabular}{|c|c|c|c|c|c|}
\hline & & Třída I & Třída II & Třída III & Třída IV \\
\hline \multicolumn{2}{|l|}{ Pohybová aktivita } & Bez omezení & Podle tolerance & Podle tolerance & Bez větší fyz. námahy \\
\hline \multicolumn{2}{|l|}{$\begin{array}{l}\text { Tělesná výchova } \\
\text { ve škole }\end{array}$} & Bez omezení & S úlevami & Nevhodná & Nevhodná \\
\hline \multicolumn{2}{|l|}{ Rekreační sport } & Bez omezení & Možný (indiv. přístup) & S nízkou zátěží & S nízkou zátěží \\
\hline \multicolumn{2}{|l|}{ Závodní sport } & Možný & Nevhodný & Zcela nevhodný & Zakázaný \\
\hline \multicolumn{2}{|l|}{ NYHA } & I & II & III-IV & \\
\hline \multirow{2}{*}{\multicolumn{2}{|c|}{$\begin{array}{l}\text { Hemodynamické } \\
\text { projevy }\end{array}$}} & Žádné & Mírné & Střední až významné & \\
\hline & & Nevýznamné & Středně významné & Významné & $\begin{array}{l}\text { Vysoké riziko náhlého } \\
\text { úmrtí }\end{array}$ \\
\hline \multicolumn{2}{|l|}{$\begin{array}{l}\text { Dysrytmie } \\
\text { Holter/Zátěžz }\end{array}$} & Nepřítomny/nevýznamné & Kontrolované léčbou & Závažné & \\
\hline Holter/Zátěž & & $\begin{array}{l}\text { Normální/nevýznamné } \\
\text { dysrytmie, bez } \\
\text { ischemických změn }\end{array}$ & $\begin{array}{l}\text { Normální/nevýznamné } \\
\text { dysrytmie, bez } \\
\text { ischemických zmèn }\end{array}$ & $\begin{array}{l}\text { Závažné dysrytmie/ } \\
\text { ischemické změny }\end{array}$ & \\
\hline \multirow[t]{2}{*}{$\begin{array}{l}\text { Defekt } \\
\text { síňového } \\
\text { septa }\end{array}$} & nativní & $\begin{array}{l}\text { - nevýznamný zkrat } \\
\text { - bez plicní hypertenze }\end{array}$ & $\begin{array}{l}\text { - středně významný zkrat } \\
\text { - bez závažné plicní } \\
\text { hypertenze } \\
\text { Doporučení: } \\
\text { - zvážit uzávěr defektu }\end{array}$ & $\begin{array}{l}\text { - významný zkrat } \\
\text { - závažná plicní hypertenze } \\
\text { - srdeční selhání } \\
\text { Doporučení: } \\
\text { - zvážit uzávěr defektu }\end{array}$ & $\begin{array}{l}\text { - těžká plicní hypertenze } \\
\text { (Eisenmengerův } \\
\text { syndrom) }\end{array}$ \\
\hline & po int. & $\begin{array}{l}\text { - bez významnějších reziduí } \\
\text { nebo následků } \\
\text { - normální srdeční funkce } \\
\text { - bez plicní hypertenze } \\
\text { - zátěžové vyšetření: bez } \\
\text { závažných dysrytmií nebo } \\
\text { ischemických změn } \\
\text { Doporučení: } \\
\text { - závodní sporty za } 6 \text { mě- } \\
\text { síců, rekreační sporty } \\
\text { za } 3 \text { měsíce po intervenci }\end{array}$ & $\begin{array}{l}\text { - středně závažná rezidua } \\
\text { nebo následky } \\
\text { - perzistující méně závažná } \\
\text { plicní hypertenze } \\
\text { Doporučení: } \\
\text { - rekreační sporty } \\
\text { za } 3 \text { měsíce } \\
\text { po intervenci } \\
\text { - zvážit reintervenci }\end{array}$ & $\begin{array}{l}\text { - závažná rezidua nebo } \\
\text { následky } \\
\text { - perzistující závažná plicní } \\
\text { hypertenze } \\
\text { Doporučení: } \\
\text { - zvážit reintervenci }\end{array}$ & $\begin{array}{l}\text { Stejně jako třída III } \\
\text { - těžká perzistující plicní } \\
\text { hypertenze } \\
\text { - synkopy, presynkopy }\end{array}$ \\
\hline \multirow[t]{2}{*}{$\begin{array}{l}\text { Defekt } \\
\text { komorového } \\
\text { septa }\end{array}$} & nativní & $\begin{array}{l}\text { - nevýznamný zkrat } \\
\text { - bez plicní hypertenze }\end{array}$ & $\begin{array}{l}\text { - středně významný zkrat } \\
\text { - bez závažné plicní } \\
\text { hypertenze } \\
\text { Doporučení: } \\
\text { - zvážit uzávěr defektu }\end{array}$ & $\begin{array}{l}\text { - významný zkrat } \\
\text { - závažná plicní hypertenze } \\
\text { - srdeční selhání } \\
\text { Doporučení: } \\
\text { - zvážit uzávěr defektu }\end{array}$ & $\begin{array}{l}\text { - těžká plicní hypertenze } \\
\text { (Eisenmengerův } \\
\text { syndrom) }\end{array}$ \\
\hline & po int. & $\begin{array}{l}\text { - bez významnějších reziduí } \\
\text { nebo následků } \\
\text { - normální srdeční funkce } \\
\text { - bez plicní hypertenze } \\
\text { - zátěžové vyšetření: bez } \\
\text { závažných dysrytmií nebo } \\
\text { ischemických změn } \\
\text { Doporučení: } \\
\text { - závodní sporty za } 6 \text { mě- } \\
\text { síců, rekreační sporty } \\
\text { za } 3 \text { měsíce po intervenci }\end{array}$ & $\begin{array}{l}\text { - středně závažná rezidua } \\
\text { nebo následky } \\
\text { - perzistující méně závažná } \\
\text { plicní hypertenze } \\
\text { Doporučení: } \\
\text { - rekreační sporty } \\
\text { za } 3 \text { měsíce po intervenci } \\
\text { - zvážit reintervenci }\end{array}$ & $\begin{array}{l}\text { - závažná rezidua nebo } \\
\text { následky } \\
\text { - perzistující závažná plicní } \\
\text { hypertenze } \\
\text { Doporučení: } \\
\text { - zvážit reintervenci }\end{array}$ & $\begin{array}{l}\text { Stejně jako třída III } \\
\text { - těžká perzistující plicní } \\
\text { hypertenze } \\
\text { - } \text { synkopy, presynkopy }\end{array}$ \\
\hline \multirow[t]{2}{*}{$\begin{array}{l}\text { Inkompletní } \\
\text { defekt AV } \\
\text { septa }\end{array}$} & nativní & $\begin{array}{l}\text { - nevýznamný zkrat } \\
\text { - bez plicní hypertenze } \\
\text { - nevýznamná mitrální } \\
\text { insuficience }\end{array}$ & $\begin{array}{l}\text { - středně významný zkrat } \\
\text { - středně významná } \\
\text { mitrální insuficience } \\
\text { - bez závažné plicní } \\
\text { hypertenze } \\
\text { Doporučení: } \\
\text { - zvážit operaci }\end{array}$ & $\begin{array}{l}\text { - významný zkrat } \\
\text { - závažná plicní hypertenze } \\
\text { - významná mitrální } \\
\text { insuficience } \\
\text { - srdeční selhání } \\
\text { Doporučení: } \\
\text { - zvážit operaci }\end{array}$ & $\begin{array}{l}\text { - těžká plicní hypertenze } \\
\text { (Eisenmengerův } \\
\text { syndrom) }\end{array}$ \\
\hline & po int. & $\begin{array}{l}\text { - bez významnějších } \\
\text { reziduí nebo následků } \\
\text { - normální srdeční funkce } \\
\text { - bez plicní hypertenze } \\
\text { - zátěžové vyšetření: } \\
\text { bez závažných dysrytmií } \\
\text { nebo ischemických změn } \\
\text { Doporučení: } \\
\text { - závodní sporty za } 6 \text { měsíců, } \\
\text { rekreační sporty za } 3 \text { měsíce } \\
\text { po intervenci }\end{array}$ & $\begin{array}{l}\text { - středně závažná rezidua } \\
\text { nebo následky } \\
\text { - perzistující méně závažná } \\
\text { plicní hypertenze } \\
\text { Doporučení: } \\
\text { - rekreační sporty } \\
\text { za } 3 \text { měsíce } \\
\text { po intervenci } \\
\text { - zvážit reintervenci }\end{array}$ & $\begin{array}{l}\text { - závažná rezidua nebo } \\
\text { následky } \\
\text { - perzistující závažná plicní } \\
\text { hypertenze } \\
\text { Doporučení: } \\
\text { - zvážit reintervenci }\end{array}$ & $\begin{array}{l}\text { Stejně jako třída III } \\
\text { - těžká perzistující plicní } \\
\text { hypertenze } \\
\text { - synkopy, presynkopy }\end{array}$ \\
\hline
\end{tabular}


Tab. 3 Vrozené srdeční vady - pokračování

\begin{tabular}{|c|c|c|c|c|c|}
\hline & & Třída I & Třída II & Třída III & Třída IV \\
\hline \multirow{2}{*}{\multicolumn{2}{|c|}{$\begin{array}{l}\text { Pohybová aktivita } \\
\text { Tělesná výchova } \\
\text { ve škole }\end{array}$}} & Bez omezení & Podle tolerance & Podle tolerance & Bez větší fyz. námahy \\
\hline & & Bez omezení & S úlevami & Nevhodná & Nevhodná \\
\hline \multicolumn{2}{|c|}{ Rekreační sport } & Bez omezení & Možný (indiv. přístup) & S nízkou zátěží & S nízkou zátěží \\
\hline \multicolumn{2}{|c|}{ Závodní sport } & Možný & Nevhodný & Zcela nevhodný & Zakázaný \\
\hline \multirow{3}{*}{\multicolumn{2}{|c|}{$\begin{array}{l}\text { NYHA } \\
\text { Klinické obtíže } \\
\text { Hemodynamické } \\
\text { projevy }\end{array}$}} & I & II & III-IV & \\
\hline & & Žádné & Mírné & Střední až významné & \\
\hline & & Nevýznamné & Středně významné & Významné & $\begin{array}{l}\text { Vysoké riziko náhlého } \\
\text { úmrtí }\end{array}$ \\
\hline \multicolumn{2}{|c|}{ Dysrytmie } & Nepřitomny/nevýznamné & Kontrolované léčbou & Závažné & \\
\hline \multicolumn{2}{|l|}{ Holter/Zátěž } & $\begin{array}{l}\text { Normální/nevýznamné dysrytmie, } \\
\text { bez ischemických změn }\end{array}$ & $\begin{array}{l}\text { Normální/nevýznamné } \\
\text { dysrytmie, bez } \\
\text { ischemických změn }\end{array}$ & $\begin{array}{l}\text { Závažné dysrytmie/ } \\
\text { ischemické změny }\end{array}$ & \\
\hline \multirow[t]{2}{*}{$\begin{array}{l}\text { Kompletní } \\
\text { defekt AV } \\
\text { septa }\end{array}$} & nativní & \multicolumn{2}{|c|}{$\begin{array}{l}\text { Kompletní forma defektu AV septa má vždy závažné } \\
\text { hemodynamické projevy }\end{array}$} & $\begin{array}{l}\text { - významný zkrat } \\
\text { - závažná plicní hypertenze } \\
\text { - významná insuficience AV } \\
\text { chlopně } \\
\text { - srdeční selhání } \\
\text { Doporučení: } \\
\text { - zvážit operaci }\end{array}$ & $\begin{array}{l}\text { - těžká plicní hypertenze } \\
\text { (Eisenmengerův } \\
\text { syndrom) }\end{array}$ \\
\hline & po int. & $\begin{array}{l}\text { - bez významnějších reziduí } \\
\text { nebo následků } \\
\text { - normální srdeční funkce } \\
\text { - bez plicní hypertenze } \\
\text { - zátěžové vyšetření: bez závažných } \\
\text { dysrytmií nebo ischemických změn } \\
\text { Doporučení: } \\
\text { - závodní sporty za } 6 \text { měsíců, } \\
\text { rekreační sporty za } 3 \text { měsíce } \\
\text { po intervenci }\end{array}$ & $\begin{array}{l}\text { - středně závažná rezidua } \\
\text { nebo následky } \\
\text { - perzistující méně závažná } \\
\text { plicní hypertenze } \\
\text { Doporučení: } \\
\text { - rekreační sporty } \\
\text { za } 3 \text { měsíce po intervenci } \\
\text { - zvážit reintervenci }\end{array}$ & $\begin{array}{l}\text { - závažná rezidua nebo } \\
\text { následky } \\
\text { - perzistující závažná plicní } \\
\text { hypertenze } \\
\text { Doporučení: } \\
\text { - zvážit reintervenci }\end{array}$ & $\begin{array}{l}\text { Stejně jako třída III } \\
\text { - těžká perzistující plicní } \\
\text { hypertenze } \\
\text { - synkopy, presynkopy }\end{array}$ \\
\hline \multirow[t]{2}{*}{$\begin{array}{l}\text { Tepenná } \\
\text { dučej }\end{array}$} & nativní & $\begin{array}{l}\text { - nevýznamný zkrat } \\
\text { - bez plicní hypertenze }\end{array}$ & $\begin{array}{l}\text { - středně významný zkrat } \\
\text { - bez závažné plicní } \\
\text { hypertenze } \\
\text { Doporučení: } \\
\text { - zvážit uzávěr dučeje }\end{array}$ & $\begin{array}{l}\text { - významný zkrat } \\
\text { - závažná plicní hypertenze } \\
\text { - srdeční selhání } \\
\text { Doporučení: } \\
\text { - zvážit uzávěr dučeje }\end{array}$ & $\begin{array}{l}\text { - těžká plicní hypertenze } \\
\text { (Eisenmengerův } \\
\text { syndrom) }\end{array}$ \\
\hline & po int. & $\begin{array}{l}\text { - bez významnějších reziduí nebo } \\
\text { následků } \\
\text { - normální srdeční funkce } \\
\text { - bez plicní hypertenze } \\
\text { Doporučení: } \\
\text { - závodní sporty za } 3 \text { měsíce, } \\
\text { rekreační sporty za } 1 \text { měsíc } \\
\text { po intervenci }\end{array}$ & $\begin{array}{l}\text { - středně závažná rezidua } \\
\text { nebo následky } \\
\text { - perzistující méně závažná } \\
\text { plicní hypertenze } \\
\text { Doporučení: } \\
\text { - rekreační sporty } \\
\text { za } 1 \text { měsíc po intervenci } \\
\text { - zvážit reintervenci }\end{array}$ & $\begin{array}{l}\text { - závažná rezidua nebo } \\
\text { následky } \\
\text { - perzistující závažná plicní } \\
\text { hypertenze } \\
\text { Doporučení: } \\
\text { - zvážit reintervenci }\end{array}$ & $\begin{array}{l}\text { Stejně jako třída III } \\
\text { - těžká perzistující plicní } \\
\text { hypertenze } \\
\text { - synkopy, presynkopy }\end{array}$ \\
\hline $\begin{array}{l}\text { Úplný } \\
\text { anomální } \\
\text { návrat } \\
\text { plicních žil }\end{array}$ & po int. & $\begin{array}{l}\text { - bez významnějších reziduí } \\
\text { nebo následků } \\
\text { - normální srdeční funkce } \\
\text { - bez plicní hypertenze } \\
\text { - zátěžové vyšetření: bez závažných } \\
\text { dysrytmií nebo ischemických změn } \\
\text { Doporučení: } \\
\text { - závodní sporty za } 6 \text { měsíců, } \\
\text { rekreační sporty za } 3 \text { měsíce } \\
\text { po intervenci }\end{array}$ & $\begin{array}{l}\text { - středně závažná rezidua } \\
\text { nebo následky } \\
\text { - perzistující méně závažná } \\
\text { plicní hypertenze } \\
\text { Doporučení: } \\
\text { - rekreační sporty } \\
\text { za } 3 \text { měsíce po intervenci } \\
\text { - zvážit reintervenci }\end{array}$ & $\begin{array}{l}\text { - závažná rezidua nebo } \\
\text { následky } \\
\text { - perzistující závažná plicní } \\
\text { hypertenze } \\
\text { Doporučení: } \\
\text { - zvážit reintervenci }\end{array}$ & $\begin{array}{l}\text { Stejně jako třída III } \\
\text { - těžká perzistující plicní } \\
\text { hypertenze } \\
\text { - synkopy, presynkopy }\end{array}$ \\
\hline $\begin{array}{l}\text { Koarktace } \\
\text { aorty }\end{array}$ & nativní & $\begin{array}{l}\text { - } \text { normální klidový TK } \\
\text { - gradient HK/DK } \leq 20 \text { mm Hg } \\
\text { - zátěžové vyšetření: maximální } \\
\text { syst. TK při zatěži } \leq 230 \text { mm Hg } \\
\text { - normální kořen aorty (viz } \\
\text { bikuspidální aort. chlopeň) } \\
\text { Doporučení: } \\
\text { - závodní sporty s vysokou } \\
\text { statickou zátěží jsou nevhodné } \\
\text { - pravidelné kontroly TK } \\
\text { a zátěžového vyšetření }\end{array}$ & $\begin{array}{l}\text { - středně závažná hyper- } \\
\text { tenze } \\
\text { - } \text { gradient } \\
\text { HK/DK > } 20 \text { mm Hg } \\
\text { - maximální syst. TK při } \\
\text { zatěži > } 230 \text { mm Hg } \\
\text { - mírná až střední } \\
\text { dilatace kořene aorty (viz } \\
\text { bikuspidální aort. chlopeň) } \\
\text { Doporučení: } \\
\text { - zvážit intervenci }\end{array}$ & $\begin{array}{l}\text { - závažná hypertenze } \\
\text { - srdeční selhání } \\
\text { Doporučení: } \\
\text { - zvážit intervenci } \\
\text { ) }\end{array}$ & $\begin{array}{l}\text { - významná dilatace koře- } \\
\text { ne aorty (viz bikuspidální } \\
\text { aort. chlopeň) } \\
\text { - méněcenná stěna aorty } \\
\text { - aneurysma isthmu aorty } \\
\text { Doporučení: } \\
\text { - intervence }\end{array}$ \\
\hline
\end{tabular}


Tab. 3 Vrozené srdeční vady - pokračování

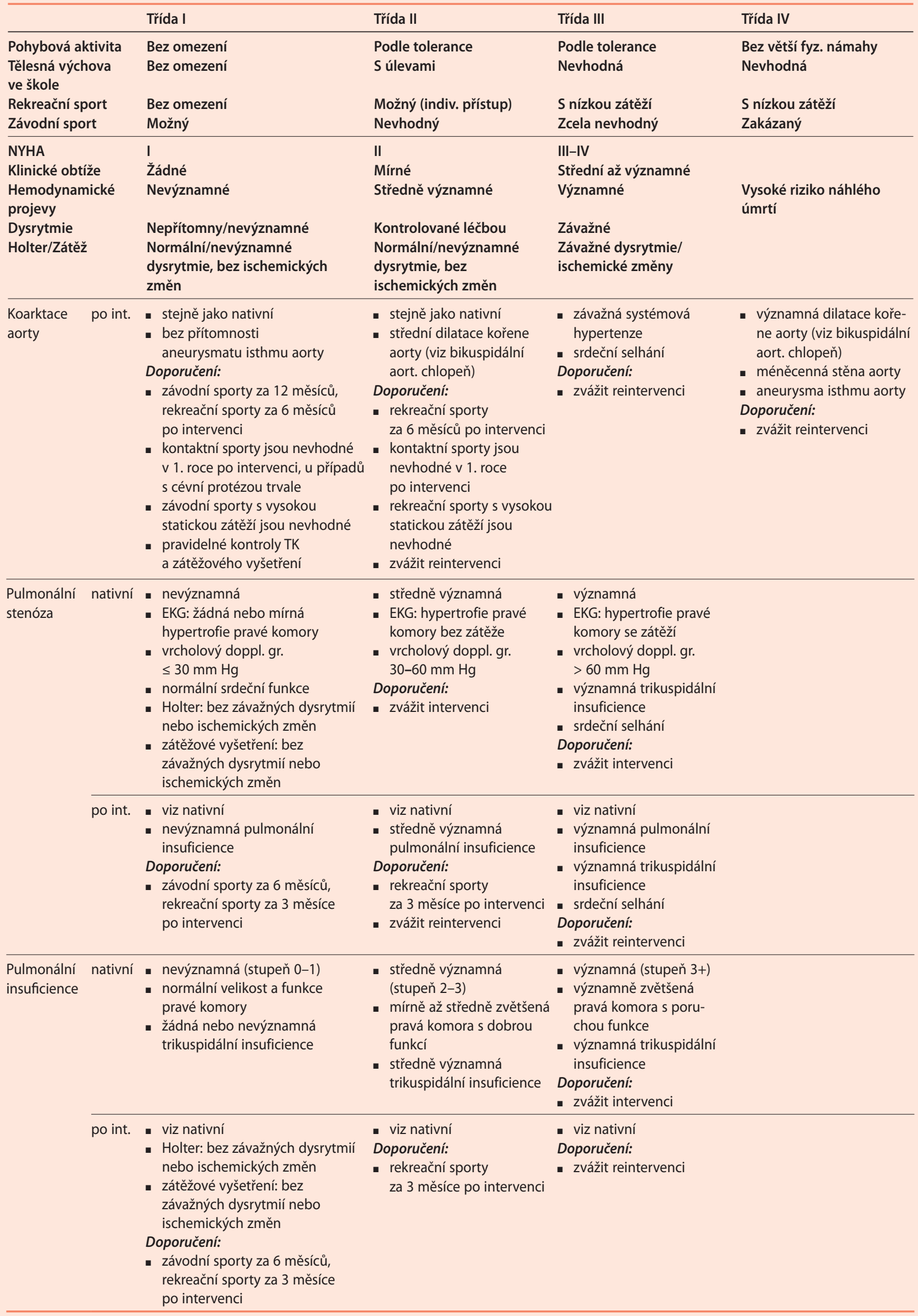


Tab. 3 Vrozené srdeční vady - pokračování

\begin{tabular}{|c|c|c|c|c|c|}
\hline & & Třída I & Třída II & Třída III & Třída IV \\
\hline \multirow{4}{*}{\multicolumn{2}{|c|}{$\begin{array}{l}\text { Pohybová aktivita } \\
\text { Tělesná výchova } \\
\text { ve škole } \\
\text { Rekreační sport } \\
\text { Závodní sport }\end{array}$}} & Bez omezení & Podle tolerance & Podle tolerance & Bez větší fyz. námahy \\
\hline & & Bez omezení & S úlevami & Nevhodná & Nevhodná \\
\hline & & Bez omezení & Možný (indiv. přístup) & S nízkou zátěží & S nízkou zátěží \\
\hline & & Možný & Nevhodný & Zcela nevhodný & Zakázaný \\
\hline \multirow{4}{*}{\multicolumn{2}{|c|}{$\begin{array}{l}\text { NYHA } \\
\text { Klinické obtíže } \\
\text { Hemodynamické } \\
\text { projevy } \\
\text { Dysrytmie } \\
\text { Holter/Zátěž }\end{array}$}} & I & II & III-IV & \multirow{5}{*}{$\begin{array}{l}\text { Vysoké riziko náhlého } \\
\text { úmrtí }\end{array}$} \\
\hline & & Žádné & Mírné & Střední až významné & \\
\hline & & Nevýznamné & Středně významné & Významné & \\
\hline & & Nepřítomny/nevýznamné & Kontrolované léčbou & Závažné & \\
\hline Holter/Zátěż & 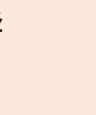 & $\begin{array}{l}\text { Normální/nevýznamné dysrytmie, } \\
\text { bez ischemických změn }\end{array}$ & $\begin{array}{l}\text { Normální/nevýznamné } \\
\text { dysrytmie, bez } \\
\text { ischemických změn }\end{array}$ & $\begin{array}{l}\text { Závažné dysrytmie/ } \\
\text { ischemické změny }\end{array}$ & \\
\hline \multirow[t]{2}{*}{$\begin{array}{l}\text { Aortální } \\
\text { stenóza }\end{array}$} & nativní & $\begin{array}{l}\text { - } \text { nevýznamná } \\
\text { - bez symptomů a synkop nebo } \\
\text { - EKG: normální } \\
\text { - bez závažných dysrytmií } \\
\text { (včetně anamnézy) } \\
\text { - doppl. gr.: vrcholový } \\
\text { < } 40 \text { mm Hg; stř. } \leq 20 \text { mm Hg } \\
\text { - normální srdeční funkce } \\
\text { - normální kořen aorty } \\
\text { (viz bikuspidální aort. chlopeň) } \\
\text { - Holter: bez závažných dysrytmií } \\
\text { nebo ischemických změn } \\
\text { - zátěžové vyšetření: } \\
\text { bez závažných dysrytmií } \\
\text { nebo ischemických změn } \\
\text { Doporučení: } \\
\text { - závodní sporty s vysokou } \\
\text { statickou a dynamickou } \\
\text { zátěží jsou nevhodné }\end{array}$ & $\begin{array}{l}\text { - středně významná } \\
\text { - bez symptomů } \\
\text { a synkop nebo } \\
\text { presynkop v anamnéze } \\
\text { - EKG: hypetrofie levé } \\
\text { komory bez zátěže } \\
\text { - bez závažných dysrytmií } \\
\text { (včetně anamnézy) } \\
\text { - doppl. gr.: vrcholový } \\
40-70 \text { mm Hg; } \\
\text { stř. } 21-40 \text { mm Hg } \\
\text { - normální srdeční funkce } \\
\text { - střední dilatace kořene } \\
\text { aorty (viz bikuspidální } \\
\text { aort. chlopeň) } \\
\text { - Holter: bez závažných } \\
\text { dysrytmií nebo } \\
\text { ischemických změn } \\
\text { - zátěžové vyšetření: } \\
\text { bez závažných dysrytmií } \\
\text { nebo ischemických změn }\end{array}$ & $\begin{array}{l}\text { - významná } \\
\text { - EKG: hypetrofie levé } \\
\text { komory se zátěží } \\
\text { - závažné dysrytmie } \\
\text { - doppl. gr.: vrcholový } \\
>70 \mathrm{~mm} \mathrm{Hg;} \\
\text { stř. > } 40 \mathrm{~mm} \mathrm{Hg} \\
\text { - dysfunkce LV } \\
\text { - Holter: závažné } \\
\text { dysrytmie nebo } \\
\text { ischemické změny } \\
\text { - zátěžové vyšetření } \\
\text { závažné dysrytmie nebo } \\
\text { ischemické změny } \\
\text { Doporučení: } \\
\text { - zvážit intervenci }\end{array}$ & $\begin{array}{l}\text { Stejně jako třída III } \\
\text { - synkopy, presynkopy, } \\
\text { život ohrožující dysrytmie } \\
\text { (včetně anamnézy) } \\
\text { - významná dilatace koře- } \\
\text { ne aorty (viz bikuspidální } \\
\text { aort. chlopeň) } \\
\text { Doporučení: } \\
\text { - intervence }\end{array}$ \\
\hline & po int. & $\begin{array}{l}\text { - viz nativní } \\
\text { - nevýznamná aortální insuficience } \\
\text { Doporučení: } \\
\text { - závodní sporty za } 6 \text { měsíců, } \\
\text { rekreační sporty za } 3 \text { měsíce } \\
\text { po intervenci } \\
\text { - závodní sporty s vysokou } \\
\text { statickou a dynamickou zátěží } \\
\text { jsou nevhodné }\end{array}$ & $\begin{array}{l}\text { - viz nativní } \\
\text { - středně významná } \\
\text { aortální insuficience } \\
\text { Doporučení: } \\
\text { - rekreační sporty } \\
\text { za } 3 \text { měsíce } \\
\text { po intervenci }\end{array}$ & $\begin{array}{l}\text { - viz nativní } \\
\text { - významná aortální } \\
\text { insuficience } \\
\text { - srdeční selhání } \\
\text { Doporučení: } \\
\text { - zvážit reintervenci }\end{array}$ & $\begin{array}{l}\text { Stejně jako třída III } \\
\text { - synkopy, presynkopy, } \\
\text { život ohrožující dysrytmie } \\
\text { (včetně anamnézy) } \\
\text { - významná dilatace koře- } \\
\text { ne aorty (viz bikuspidální } \\
\text { aort. chlopeň) } \\
\text { Doporučení: } \\
\text { - reintervence }\end{array}$ \\
\hline \multirow[t]{2}{*}{$\begin{array}{l}\text { Aortální } \\
\text { insuficience }\end{array}$} & nativní & $\begin{array}{l}\text { - nevýznamná (stupeň 0-1) } \\
\text { - EKG: normální } \\
\text { - bez závažných dysrytmií } \\
\text { (včetně anamnézy) } \\
\text { - normální funkce LV } \\
\text { - normální kořen aorty (viz } \\
\text { bikuspidální aort. chlopeň) } \\
\text { - Holter: bez závažných dysrytmií } \\
\text { nebo ischemických změn } \\
\text { - zátěžové vyšetření: bez } \\
\text { závažných dysrytmií nebo } \\
\text { ischemických změn }\end{array}$ & $\begin{array}{l}\text { - středně významná } \\
\text { (stupeň 2-3) } \\
\text { - EKG: bez zátěžových změn } \\
\text { - bez závažných dysrytmií } \\
\text { (včetně anamnézy) } \\
\text { - středně zvětšená LV } \\
\text { s normální funkcí } \\
\text { - střední dilatace kořene } \\
\text { aorty (viz bikuspidální } \\
\text { aort. chlopeň) } \\
\text { - Holter: bez závažných } \\
\text { dysrytmií nebo } \\
\text { ischemických změn } \\
\text { - zátěžové vyšetření: bez } \\
\text { závažných dysrytmií nebo } \\
\text { ischemických změn }\end{array}$ & $\begin{array}{l}\text { - významná (stupeň 3+) } \\
\text { - EKG: zátěžové změny } \\
\text { - významně zvětšená LV se } \\
\text { sníženou funkcí } \\
\text { - Holter: závažné dysrytmie } \\
\text { nebo ischemické změny } \\
\text { - zátěžové vyšetření } \\
\text { závažné dysrytmie nebo } \\
\text { ischemické změny } \\
\text { Doporučení: } \\
\text { - zvážit intervenci }\end{array}$ & \\
\hline & po int. & $\begin{array}{l}\text { - viz nativní } \\
\text { Doporučení: } \\
\text { - závodní sporty za } 6 \text { měsíců, } \\
\text { rekreační sporty za } 3 \text { měsíce } \\
\text { po intervenci }\end{array}$ & $\begin{array}{l}\text { - viz nativní } \\
\text { Doporučení: } \\
\text { - rekreační sporty }\end{array}$ & - viz nativní & \\
\hline
\end{tabular}


Tab. 3 Vrozené srdeční vady - pokračování

\begin{tabular}{|c|c|c|c|c|}
\hline & Tř́́da I & Trída II & Třída III & Třída IV \\
\hline \multirow{4}{*}{$\begin{array}{l}\text { Pohybová aktivita } \\
\text { Tělesná výchova } \\
\text { ve škole } \\
\text { Rekreační sport } \\
\text { Závodní sport }\end{array}$} & Bez omezení & Podle tolerance & Podle tolerance & Bez větší fyz. námahy \\
\hline & Bez omezení & S úlevami & Nevhodná & Nevhodná \\
\hline & Bez omezení & Možný (indiv. přístup) & S nízkou zátěží & S nízkou zátěží \\
\hline & Možný & Nevhodný & Zcela nevhodný & Zakázaný \\
\hline \multirow{4}{*}{$\begin{array}{l}\text { NYHA } \\
\text { Klinické obtíže } \\
\text { Hemodynamické } \\
\text { projevy } \\
\text { Dysrytmie } \\
\text { Holter/Zátěž }\end{array}$} & I & II & III-IV & \multirow{5}{*}{$\begin{array}{l}\text { Vysoké riziko náhlého } \\
\text { úmrtí }\end{array}$} \\
\hline & Žádné & Mírné & Střední až významné & \\
\hline & Nevýznamné & Středně významné & Významné & \\
\hline & Nepřítomny/nevýznamné & Kontrolované léčbou & Závažné & \\
\hline Holter/Zátěž & $\begin{array}{l}\text { Normální/nevýznamné dysrytmie, } \\
\text { bez ischemických změn }\end{array}$ & $\begin{array}{l}\text { Normální/nevýznamné } \\
\text { dysrytmie, bez } \\
\text { ischemických změn }\end{array}$ & $\begin{array}{l}\text { Závažné dysrytmie/ } \\
\text { ischemické změny }\end{array}$ & \\
\hline $\begin{array}{l}\text { Bikuspidální } \\
\text { aortální } \\
\text { chlopeň }\end{array}$ & $\begin{array}{l}\text { - viz nativní aortální stenóza } \\
\text { - normální kořen aorty } \\
\text { - rozměr v sinech nebo asc. aorty: } \\
\text { děti }<21 \mathrm{~mm} / \mathrm{m}^{2} \\
\text { dospělí }<40 \mathrm{~mm} \\
\text { Doporučení: } \\
\text { - kontroly kardiologem }\end{array}$ & $\begin{array}{l}\text { - viz nativní aortální stenóza } \\
\text { - střední dilatace kořene } \\
\text { aorty } \\
\text { - rozměr v sinech nebo asc. } \\
\text { aorty: } \\
\text { děti } 21-25 \mathrm{~mm} / \mathrm{m}^{2} \\
\text { dospělí } 40-45 \mathrm{~mm} \\
\text { Doporučení: } \\
\text { - rekreační sporty se } \\
\text { zvýšeným rizikem } \\
\text { závažného úrazu hrudníku } \\
\text { jsou nevhodné }\end{array}$ & $\begin{array}{l}\text { - viz nativní aortální } \\
\text { stenóza } \\
\text { - významná dilatace } \\
\text { kořene aorty } \\
\text { - rozměr v sinech } \\
\text { nebo asc. aorty: } \\
\text { děti }>25 \mathrm{~mm} / \mathrm{m}^{2} \text {; } \\
\text { dospělí > } 45 \mathrm{~mm} \\
\text { Doporučení: } \\
\text { - zvážit intervenci }\end{array}$ & $\begin{array}{l}\text { - viz nativní aortální } \\
\text { stenóza }\end{array}$ \\
\hline $\begin{array}{l}\text { Prolaps } \\
\text { mitrální } \\
\text { chlopně }\end{array}$ & $\begin{array}{l}\text { - bez náhlého úmrtí ve vztahu } \\
\text { - b MVP v rodinné anamnéze } \\
\text { - bez závažných dysrytmií } \\
\text { (včetně anamnézy) } \\
\text { - bez embolizace } \\
\text { - žádná nebo nevýznamná mitrální } \\
\text { insuficience } \\
\text { - normální funkce levé komory } \\
\text { - Holter: bez závažných dysrytmií } \\
\text { nebo ischemických změn } \\
\text { - zátěžové vyšetření: bez závažných } \\
\text { dysrytmií nebo ischemických změn } \\
\text { Doporučení: } \\
\text { - kontroly kardiologem }\end{array}$ & - viz mitrální insuficience & - viz mitrální insuficience & \\
\hline \multirow[t]{2}{*}{$\begin{array}{l}\text { Mitrální } \\
\text { stenóza }\end{array}$} & $\begin{array}{l}\text { - nevýznamná } \\
\text { - doppl. gr.: stř. < } 5 \text { mm Hg } \\
\text { - bez plicní hypertenze } \\
\text { - bez závažných dysrytmií } \\
\text { (včetně anamnézy) } \\
\text { - normální velikost levé síně } \\
\text { - Holter: bez závažných dysrytmií } \\
\text { nebo ischemických změn } \\
\text { - zátěžové vyšetření: } \\
\text { bez závažných dysrytmií nebo } \\
\text { ischemických změn } \\
\text { Doporučení: } \\
\text { - závodní sporty s vysokou } \\
\text { statickou a dynamickou zátěží } \\
\text { jsou nevhodné }\end{array}$ & $\begin{array}{l}\text { - středně významná } \\
\text { - doppl. gr.: } \\
\text { stř. 5-10 mm Hg } \\
\text { - mírně až středně } \\
\text { zvětšená levá síň } \\
\text { - bez plicní hypertenze } \\
\text { - bez závažných dysrytmií } \\
\text { (včetně anamnézy) } \\
\text { - Holter: bez závažných } \\
\text { dysrytmií nebo } \\
\text { ischemických změn } \\
\text { - zátěžové vyšetření: bez } \\
\text { závažných dysrytmií nebo } \\
\text { ischemických změn }\end{array}$ & $\begin{array}{l}\text { - významná } \\
\text { - doppl. gr.: } \\
\text { stř. > } 10 \text { mm Hg } \\
\text { - významně zvětšená } \\
\text { levá síň } \\
\text { - plicní hypertenze } \\
\text { - závažné dysrytmie } \\
\text { (včetně anamnézy) } \\
\text { Doporučení: } \\
\text { - zvážit intervenci }\end{array}$ & $\begin{array}{l}\text { Stejně jako třída III } \\
\text { - těžká plicní hypertenze } \\
\text { - synkopy, presynkopy, } \\
\text { život ohrožující } \\
\text { dysrytmie (včetně } \\
\text { anamnézy) } \\
\text { Doporučení: } \\
\text { - zvážit intervenci }\end{array}$ \\
\hline & $\begin{array}{l}\text { - viz nativní } \\
\text { Doporučení: } \\
\text { - závodní sporty za } 6 \text { měsíců, } \\
\text { rekreační sporty za } 3 \text { měsíce } \\
\text { po intervenci } \\
\text { - závodní sporty s vysokou } \\
\text { statickou a dynamickou zátěží } \\
\text { jsou nevhodné }\end{array}$ & $\begin{array}{l}\text { - viz nativní } \\
\text { Doporučení: } \\
\text { - rekreační sporty } \\
\text { za } 3 \text { měsíce } \\
\text { po intervenci }\end{array}$ & $\begin{array}{l}\text { - viz nativní } \\
\text { Doporučení: } \\
\text { - zvážit intervenci/ } \\
\text { reintervenci }\end{array}$ & $\begin{array}{l}\text { - viz nativní } \\
\text { Doporučení: } \\
\text { - zvážit intervenci/ } \\
\text { reintervenci }\end{array}$ \\
\hline
\end{tabular}


Tab. 3 Vrozené srdeční vady - pokračování

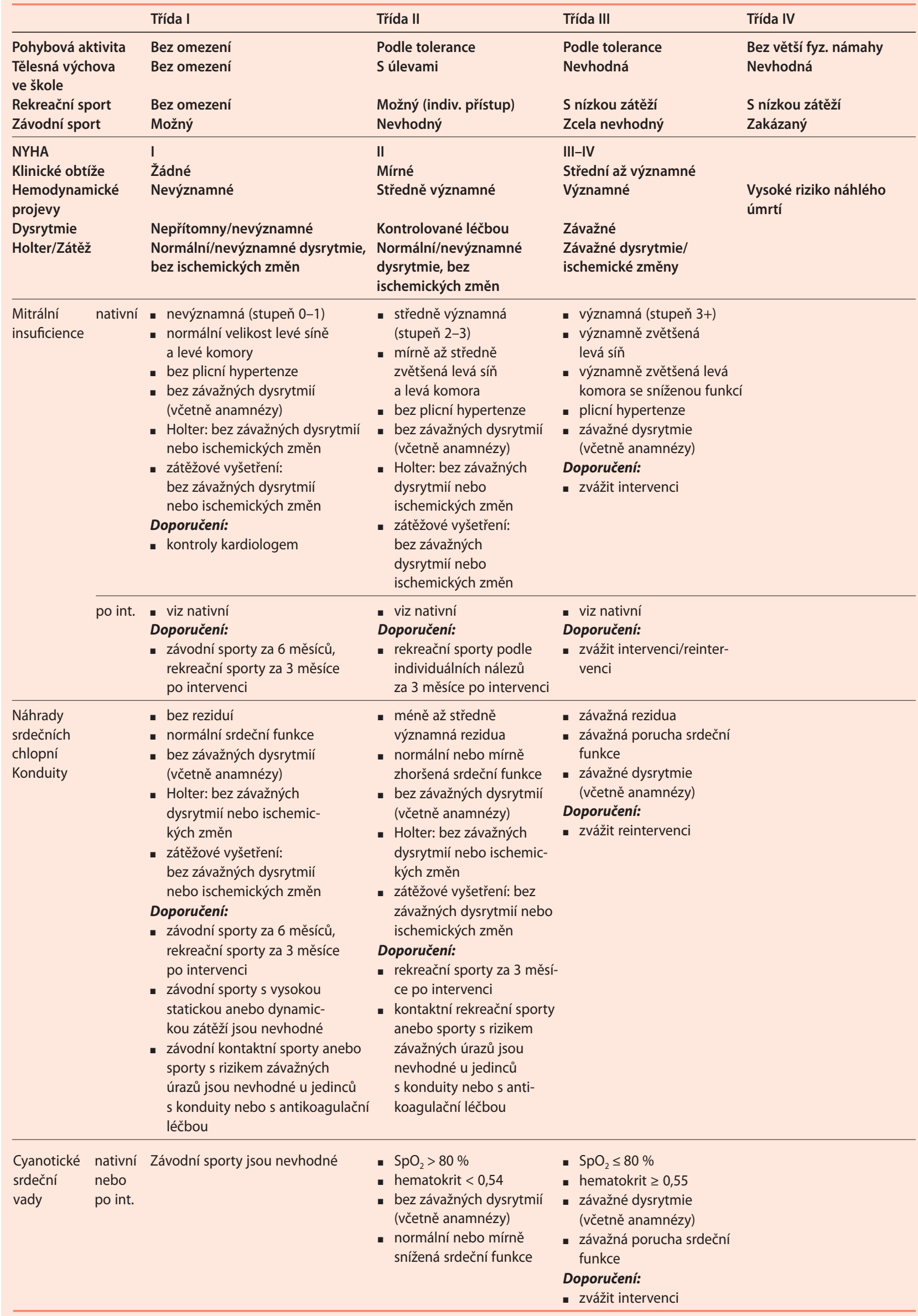


Tab. 3 Vrozené srdeční vady - pokračování

\begin{tabular}{|c|c|c|c|c|}
\hline & Třída I & Třída II & Třída III & Trída IV \\
\hline \multirow{2}{*}{$\begin{array}{l}\text { Pohybová aktivita } \\
\text { Tělesná výchova } \\
\text { ve škole }\end{array}$} & Bez omezení & Podle tolerance & Podle tolerance & Bez větší fyz. námahy \\
\hline & Bez omezení & S úlevami & Nevhodná & Nevhodná \\
\hline \multirow{2}{*}{$\begin{array}{l}\text { Rekreační sport } \\
\text { Závodní sport }\end{array}$} & Bez omezení & Možný (indiv. přístup) & S nízkou zátěží & S nízkou zátěží \\
\hline & Možný & Nevhodný & Zcela nevhodný & Zakázaný \\
\hline \multirow{3}{*}{$\begin{array}{l}\text { NYHA } \\
\text { Klinické obtíže } \\
\text { Hemodynamické } \\
\text { projevy }\end{array}$} & I & II & III-IV & \\
\hline & Žádné & Mírné & Střední až významné & \\
\hline & Nevýznamné & Středně významné & Významné & $\begin{array}{l}\text { Vysoké riziko náhlého } \\
\text { úmrtí }\end{array}$ \\
\hline \multirow{2}{*}{$\begin{array}{l}\text { Dysrytmie } \\
\text { Holter/Zátěžz }\end{array}$} & Nepř́tomny/nevýznamné & Kontrolované léčbou & Závažné & \\
\hline & $\begin{array}{l}\text { Normální/nevýznamné dysrytmie, } \\
\text { bez ischemických zmèn }\end{array}$ & $\begin{array}{l}\text { Normální/nevýznamné dysrytmie, } \\
\text { bez ischemických změn }\end{array}$ & $\begin{array}{l}\text { Závažné dysrytmie/ } \\
\text { ischemické změny }\end{array}$ & \\
\hline $\begin{array}{ll}\text { Fallotova po } \\
\text { tetralogie } & \text { int. }\end{array}$ & $\begin{array}{l}\text { - bez závažných dysrytmií } \\
\text { (včetně anamnézy) } \\
\text { - normální nebo mírně zvětšená } \\
\text { pravá komora } \\
\text { - normální nebo mírně zvýšený } \\
\text { tlak v pravé komoře } \\
\text { - bez reziduálního zkratu } \\
\text { - Holter: bez závažných dysrytmií } \\
\text { nebo ischemických změn } \\
\text { - zátěžové vyšetření: bez závažných } \\
\text { dysrytmií nebo ischemických změn } \\
\text { Doporučení: } \\
\text { - závodní sporty za } 6 \text { měsíců, rekreační } \\
\text { sporty za } 3 \text { měsíce po intervenci } \\
\text { - závodní sporty s vysokou statickou } \\
\text { anebo dynamickou zátěží jsou } \\
\text { nevhodné }\end{array}$ & $\begin{array}{l}\text { - bez závažných dysrytmií } \\
\text { (včetně anamnézy) } \\
\text { - méně nebo středně významná } \\
\text { tlaková nebo objemová zátěž } \\
\text { pravé komory } \\
\text { - Holter: bez závažných } \\
\text { dysrytmií nebo ischemických } \\
\text { změn } \\
\text { - zátěžové vyšetření: bez } \\
\text { závažných dysrytmií nebo } \\
\text { ischemických změn } \\
\text { Doporučení: } \\
\text { - rekreační sporty za } 3 \text { měsíce } \\
\text { po intervenci }\end{array}$ & $\begin{array}{l}\text { - závažné dysrytmie } \\
\text { (včetně anamnézy) } \\
\text { - významná tlaková nebo } \\
\text { objemová zátěž pravé } \\
\text { komory } \\
\text { - významná aortální } \\
\text { insuficience } \\
\text { - závažná porucha } \\
\text { srdeční funkce } \\
\text { - EKG: QRS > } 180 \text { ms } \\
\text { - Holter: závažné } \\
\text { dysrytmie nebo } \\
\text { ischemické změny } \\
\text { - zátěžové vyšetření: } \\
\text { závažné dysrytmie } \\
\text { nebo ischemické změny } \\
\text { Doporučení: } \\
\text { - zvážit reintervenci }\end{array}$ & $\begin{array}{l}\text { Stejně jako třída III } \\
\text { - synkopy, presynko- } \\
\text { py, život ohrožujíí } \\
\text { dysrytmie (včetně } \\
\text { anamnézy) } \\
\text { - pozitivní EPS }\end{array}$ \\
\hline $\begin{array}{l}\text { Transpozice } \\
\text { po fyziolo- } \\
\text { gické } \\
\text { korekci }\end{array}$ & $\begin{array}{l}\text { - bez závažných dysrytmií } \\
\text { (včetně anamnézy) } \\
\text { - normální funkce pravé komory } \\
\text { - žádná nebo stopová trikuspidální } \\
\text { insuficience } \\
\text { - Holter: bez závažných dysrytmií nebo } \\
\text { ischemických změn } \\
\text { - zátěžové vyšetření: bez závažných } \\
\text { dysrytmií nebo ischemických změn } \\
\text { Doporučení: } \\
\text { - závodní sporty za } 6 \text { měsíců, rekreační } \\
\text { sporty za } 3 \text { měsíce po intervenci } \\
\text { - možné jsou jen závodní sporty } \\
\text { s nízkou nebo dynamickou zátěží }\end{array}$ & $\begin{array}{l}\text { - bez závažných dysrytmií } \\
\text { (včetně anamnézy) } \\
\text { - normální nebo mírně snížená } \\
\text { funkce pravé komory } \\
\text { - trikuspidální insuficience } \\
\text { s2. st. } \\
\text { - Holter: bez závažných dysrytmií } \\
\text { nebo ischemických změn } \\
\text { - zátěžové vyšetření: bez } \\
\text { závažných dysrytmií nebo } \\
\text { ischemických změn } \\
\text { Doporučení } \\
\text { - rekreační sporty za } 3 \text { měsíce } \\
\text { po intervenci }\end{array}$ & $\begin{array}{l}\text { - závažné dysrytmie } \\
\text { (včetně anamnézy) } \\
\text { - dysfunkce pravé komory } \\
\text { - trikuspidální insufi- } \\
\text { cience } \geq 3 \text {. st. } \\
\text { - Holter: závažné } \\
\text { dysrytmie nebo } \\
\text { ischemické změny } \\
\text { - zátěžové vyšetření: } \\
\text { závažné dysrytmie nebo } \\
\text { ischemické změny } \\
\text { Doporučení: } \\
\text { - zvážit reintervenci }\end{array}$ & $\begin{array}{l}\text { Stejně jako třída III } \\
\text { - synkopy, presynko- } \\
\text { py, život ohrožující } \\
\text { dysrytmie (včetně } \\
\text { anamnézy) } \\
\text { - pozitivní EPS }\end{array}$ \\
\hline $\begin{array}{l}\text { Transpozice } \\
\text { po anato- } \\
\text { mické } \\
\text { korekci }\end{array}$ & $\begin{array}{l}\text { - bez závažných dysrytmií } \\
\text { (včetně anamnézy) } \\
\text { - normální funkce levé komory } \\
\text { insuficience } \\
\text { - normální funkce neoaortální } \\
\text { chlopně } \\
\text { - normální rozměr neoaortálního } \\
\text { kořene (viz bikuspidální aortální } \\
\text { chlopeň) } \\
\text { - bez stenóz koronárních artérií } \\
\text { - bez významnějších reziduí } \\
\text { a následků (např. stenóza plicnice) } \\
\text { - Holter: bez závažných dysrytmií } \\
\text { nebo ischemických změn } \\
\text { - zátěžové vyšetření: bez závažných } \\
\text { dysrytmií nebo ischemických změn } \\
\text { Doporučení: } \\
\text { - závodní sporty za } 6 \text { měsíců, rekreační } \\
\text { sporty za } 3 \text { měsíce po intervenci }\end{array}$ & $\begin{array}{l}\text { - bez závažných dysrytmií } \\
\text { (včetně anamnézy) } \\
\text { - normální nebo mírně snížená } \\
\text { funkce levé komory } \\
\text { - mitrální insuficience } \leq 2 \text {. st. } \\
\text { - neoaortální insuficience } \leq 2 \text {. st. } \\
\text { - střední dilatace neoaortálního } \\
\text { kořene (viz bikuspidální } \\
\text { aortální chlopeň) } \\
\text { - méně nebo středně závažná } \\
\text { rezidua nebo následky } \\
\text { (např. stenóza plicnice) } \\
\text { - Holter: bez závažných dysrytmií } \\
\text { nebo ischemických změn } \\
\text { - zátěžové vyšetření: bez } \\
\text { závažných dysrytmií nebo } \\
\text { ischemických změn } \\
\text { Doporučení } \\
\text { - rekreační sporty za } 3 \text { měsíce } \\
\text { po intervenci }\end{array}$ & $\begin{array}{l}\text { - závažné dysrytmie } \\
\text { (včetně anamnézy) } \\
\text { - dysfunkce levé komory } \\
\text { - } \text { mitrální insuficience } \geq 3 \text {. st. } \\
\text { cience } \geq 3 \text {. st. } \\
\text { - významná dilatace } \\
\text { neoaortálního kořene } \\
\text { (viz bikuspidální aortální } \\
\text { chlopeň) } \\
\text { - závažná rezidua nebo } \\
\text { následky (např. stenóza } \\
\text { koronárních tepen) } \\
\text { - Holter: závažné dysrytmie } \\
\text { nebo ischemické změny } \\
\text { - zátěžové vyšetření: } \\
\text { závažné dysrytmie nebo } \\
\text { ischemické změny } \\
\text { Doporučení: } \\
\text { - zvážit reintervenci }\end{array}$ & $\begin{array}{l}\text { Stejně jako třída III } \\
\text { - synkopy, presynko- } \\
\text { py, život ohrožující } \\
\text { dysrytmie (včetně } \\
\text { anamnézy) } \\
\text { - pozitivní EPS } \\
\text { í }\end{array}$ \\
\hline
\end{tabular}


Tab. 3 Vrozené srdeční vady - pokračování

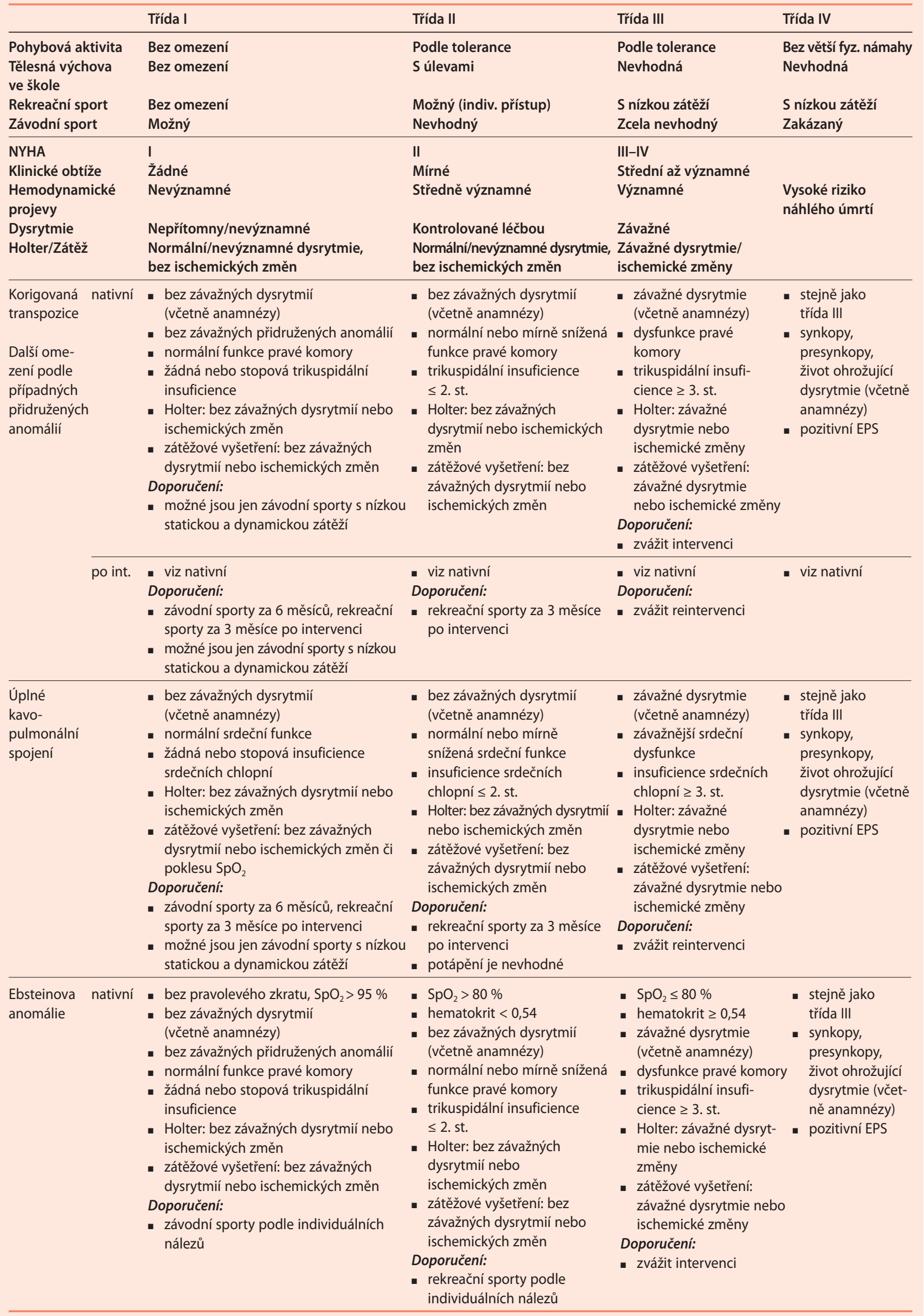


Tab. 3 Vrozené srdeční vady - pokračování

\begin{tabular}{|c|c|c|c|c|c|}
\hline & & Třída I & Třída II & Třída III & Třída IV \\
\hline \multirow{2}{*}{\multicolumn{2}{|c|}{$\begin{array}{l}\text { Pohybová aktivita } \\
\text { Tělesná výchova } \\
\text { ve škole }\end{array}$}} & Bez omezení & Podle tolerance & Podle tolerance & Bez větší fyz. námahy \\
\hline & & Bez omezení & S úlevami & Nevhodná & Nevhodná \\
\hline \multicolumn{2}{|c|}{ Rekreační sport } & Bez omezení & Možný (indiv. přístup) & S nízkou zátěží & S nízkou zátěží \\
\hline \multicolumn{2}{|c|}{ Závodní sport } & Možný & Nevhodný & Zcela nevhodný & Zakázaný \\
\hline \multirow{3}{*}{\multicolumn{2}{|c|}{$\begin{array}{l}\text { NYHA } \\
\text { Klinické obtíže } \\
\text { Hemodynamické } \\
\text { projevy }\end{array}$}} & I & II & III-IV & \\
\hline & & Žádné & Mírné & Střední až významné & \\
\hline & & Nevýznamné & Středně významné & Významné & $\begin{array}{l}\text { Vysoké riziko náhlého } \\
\text { úmrtí }\end{array}$ \\
\hline \multicolumn{2}{|c|}{ Dysrytmie } & Nepřítomny/nevýznamné & Kontrolované léčbou & Závažné & \\
\hline \multicolumn{2}{|l|}{ Holter/Zátěž } & $\begin{array}{l}\text { Normální/nevýznamné dysrytmie, } \\
\text { bez ischemických změn }\end{array}$ & $\begin{array}{l}\text { Normální/nevýznamné } \\
\text { dysrytmie, bez ischemických } \\
\text { změn }\end{array}$ & $\begin{array}{l}\text { Závažné dysrytmie/ } \\
\text { ischemické změny }\end{array}$ & \\
\hline $\begin{array}{l}\text { Ebsteinova } \\
\text { anomálie }\end{array}$ & po int. & $\begin{array}{l}\text { - viz nativní } \\
\text { Doporučení: } \\
\text { - závodní sporty za } 6 \text { měsíců, rekreační } \\
\text { sporty za } 3 \text { měsíce po intervenci } \\
\text { - možné jsou jen závodní sporty } \\
\text { s nízkou statickou a dynamickou } \\
\text { zátěží }\end{array}$ & $\begin{array}{l}\text { - viz nativní } \\
\text { Doporučení: } \\
\text { - rekreační sporty }\end{array}$ & $\begin{array}{l}\text { - viz nativní } \\
\text { Doporučení: } \\
\text { - zvážit reintervenci }\end{array}$ & - viz nativní \\
\hline \multirow[t]{2}{*}{$\begin{array}{l}\text { Anomálie } \\
\text { koronárních } \\
\text { tepen }\end{array}$} & nativní & \multicolumn{2}{|c|}{$\begin{array}{l}\text { Individuální př́stup podle základní diagnózy } \\
\text { (např. podle významnosti a lokalizace a-v píštěle) }\end{array}$} & $\begin{array}{l}\text { - } \text { anomální odstup } \\
\text { z nepronárníslušného sinu } \\
\text { pokud probíhá mezi } \\
\text { aortou a plicnicí } \\
\text { - anomální odstup } \\
\text { koronární arterie } \\
\text { z plicnice } \\
\text { - závažné dysrytmie } \\
\text { (včetně anamnézy) } \\
\text { Doporučení: } \\
\text { - intervence }\end{array}$ & $\begin{array}{l}\text { - } \text { stejně jako třída III } \\
\text { - } \text { synkopy, presynko- } \\
\text { dysrivot ohrožující } \\
\text { anamnézy) (včetně } \\
\text { - } \text { ischemické změny } \\
\text { na EKG } \\
\text { - porucha srdeční } \\
\text { funkce } \\
\text { - významná mitrální } \\
\text { insuficience } \\
\text { - pozitivní EPS } \\
\text { Doporučení: } \\
\text { - intervence }\end{array}$ \\
\hline & po int. & $\begin{array}{l}\text { - bez závažných dysrytmií (včetně } \\
\text { anamnézy) } \\
\text { - normální funkce levé komory } \\
\text { - žádná nebo stopová mitrální } \\
\text { insuficience } \\
\text { - Holter: bez závažných dysrytmií } \\
\text { nebo ischemických změn } \\
\text { - zátěžové vyšetření: bez závažných } \\
\text { dysrytmií nebo ischemických změn } \\
\text { Doporučení: } \\
\text { - závodní sporty podle individuálních } \\
\text { nálezů za } 6 \text { měsíců, rekreační sporty } \\
\text { za } 3 \text { měsíce po intervenci }\end{array}$ & $\begin{array}{l}\text { - bez závažných dysrytmií } \\
\text { (včetně anamnézy) } \\
\text { - normální nebo mírně snížená } \\
\text { funkce levé komory } \\
\text { - mitrální insuficience } \leq 2 \text {. st. } \\
\text { - Holter: bez závažných } \\
\text { dysrytmií nebo ischemických } \\
\text { změn } \\
\text { - zátěžové vyšetření: bez } \\
\text { závažných dysrytmií nebo } \\
\text { ischemických změn } \\
\text { Doporučení: } \\
\text { - rekreační sporty podle } \\
\text { individuálních nálezů } \\
\text { za } 3 \text { měsíce po intervenci }\end{array}$ & $\begin{array}{l}\text { - závažné dysrytmie } \\
\text { (včetně anamnézy) } \\
\text { - dysfunkce levé } \\
\text { komory } \\
\text { - mitrální insufi- } \\
\text { cience } \geq 3 \text {. st. } \\
\text { - závažná rezidua nebo } \\
\text { následky (např. stenóza } \\
\text { koronárních tepen) } \\
\text { - Holter: závažné } \\
\text { dysrytmie nebo } \\
\text { ischemické změny } \\
\text { - zátěžové vyšetření: } \\
\text { závažné dysrytmie } \\
\text { nebo ischemické změny } \\
\text { Doporučení: } \\
\text { - zvážit reintervenci }\end{array}$ & $\begin{array}{l}\text { Stejně jako třída III } \\
\text { - synkopy, presynko- } \\
\text { py, život ohrožující } \\
\text { dysrytmie (včetně } \\
\text { anamnézy) } \\
\text { - pozitivní EPS } \\
\text { y }\end{array}$ \\
\hline $\begin{array}{l}\text { Plicní } \\
\text { hypertenze } \\
\text { u vrozených } \\
\text { srdečních } \\
\text { vad; } \\
\text { Eisenmen- } \\
\text { gerův } \\
\text { syndrom }\end{array}$ & $\begin{array}{l}\text { nativní } \\
\text { nebo } \\
\text { po int. }\end{array}$ & Zákaz závodních sportů & $\begin{array}{l}\text { - Mírný stupeň plicní hypertenze } \\
\text { - Holter: bez závažných } \\
\text { dysrytmií nebo } \\
\text { ischemických změn } \\
\text { - zátěžové vyšetření: bez } \\
\text { závažných dysrytmií nebo } \\
\text { ischemických změn } \\
\text { Doporučení: } \\
\text { - rekreační sporty podle } \\
\text { individuálních nálezů } \\
\text { - rekreační sporty s vysokou } \\
\text { statickou anebo dynamickou } \\
\text { zátěží jsou nevhodné }\end{array}$ & $\begin{array}{l}\text { - vyšší stupně plicní } \\
\text { hypertenze } \\
\text { Doporučení: } \\
\text { - individuální přístup }\end{array}$ & $\begin{array}{l}\text { - významná plicní } \\
\text { hypertenze } \\
\text { - synkopy, } \\
\text { presynkopy } \\
\text { (včetně anamnézy) }\end{array}$ \\
\hline
\end{tabular}


Tab. 4 Získaná a hereditární kardiovaskulární onemocnění

\begin{tabular}{|c|c|c|c|c|}
\hline & Třída I & Třída II & Trída III & Trída IV \\
\hline $\begin{array}{l}\text { Pohybová aktivita } \\
\text { Tělesná výchova } \\
\text { ve škole }\end{array}$ & $\begin{array}{l}\text { Bez omezení } \\
\text { Bez omezení }\end{array}$ & $\begin{array}{l}\text { Podle tolerance } \\
\text { S úlevami }\end{array}$ & $\begin{array}{l}\text { Podle tolerance } \\
\text { Nevhodná }\end{array}$ & $\begin{array}{l}\text { Bez větší fyz. námahy } \\
\text { Nevhodná }\end{array}$ \\
\hline Rekreační sport & Bez omezení & Možný (indiv. přístup) & S nízkou zátěží & S nízkou zátěží \\
\hline Závodní sport & Možný & Nevhodný & Zcela nevhodný & Zakázaný \\
\hline NYHA & I & II & III-IV & \\
\hline Klinické obtíže & Žádné & Mírné & Střední až významné & \\
\hline $\begin{array}{l}\text { Hemodynamické } \\
\text { projevy }\end{array}$ & Nevýznamné & Středně významné & Významné & $\begin{array}{l}\text { Vysoké riziko náhlého } \\
\text { úmrtí }\end{array}$ \\
\hline Dysrytmie & Nepřítomny/nevýznamné & Kontrolované léčbou & Závažné & \\
\hline Holter/Zátěž & $\begin{array}{l}\text { Normální/nevýznamné } \\
\text { dysrytmie, bez } \\
\text { ischemických zmèn }\end{array}$ & $\begin{array}{l}\text { Normální/nevýznamné } \\
\text { dysrytmie, bez } \\
\text { ischemických změn }\end{array}$ & $\begin{array}{l}\text { Závažné dysrytmie/ } \\
\text { ischemické změny }\end{array}$ & \\
\hline $\begin{array}{l}\text { Primární } \\
\text { hypertenze }\end{array}$ & $\begin{array}{l}\text { a) vysoký normální tlak } \\
\text { (<95. percentil) } \\
\text { b) hypertenze 1. stupně } \\
\text { kontrolovaná léčbou } \\
\text { - normální EKG } \\
\text { - normální srdeční rozměry } \\
\text { a funkce } \\
\text { - normální reakce TK při } \\
\text { zátěžovém vyšetření } \\
\text { - bez orgánových změn } \\
\text { Doporučení: } \\
\text { - závodní sporty } \\
\text { bez omezení } \\
\text { - pravidelné kontroly TK } \\
\text { a zátěžového vyšetření }\end{array}$ & \multicolumn{3}{|c|}{$\begin{array}{l}\text { Hypertenze } 2 \text {. stupně } \\
\text { Závažná hypertenze nedostatečně kontrolovaná léčbou nebo } \\
\text { s orgánovými změnami } \\
\text { Doporučení: } \\
\text { - rekreační sporty podle individuálních nálezů } \\
\text { - pravidelné kontroly TK a zátěžového vyšetření }\end{array}$} \\
\hline $\begin{array}{l}\text { Sekundární } \\
\text { hypertenze }\end{array}$ & $\begin{array}{l}\text { Viz primární hypertenze } \\
\text { Doporučení: } \\
\text { - omezení podle základního } \\
\text { onemocnění }\end{array}$ & \multicolumn{3}{|c|}{$\begin{array}{l}\text { Viz primární hypertenze } \\
\text { Doporučení: } \\
\text { - omezení podle základního onemocnění }\end{array}$} \\
\hline $\begin{array}{l}\text { Kawasakiho } \\
\text { choroba }\end{array}$ & $\begin{array}{l}\text { Za } 12 \text { měsíců po proběhlém } \\
\text { onemocnění } \\
\text { - bez postižení koronárních } \\
\text { tepen } \\
\text { - normální EKG } \\
\text { - normální srdeční funkce } \\
\text { - Holter: bez závažných } \\
\text { dysrytmií nebo ischemic- } \\
\text { kých změn } \\
\text { - zátěžové vyšetření: bez } \\
\text { závažných dysrytmií nebo } \\
\text { ischemických změn } \\
\text { Doporučení: } \\
\text { - závodní sporty podle } \\
\text { individuálních nálezů } \\
\text { - kontroly kardiologem }\end{array}$ & $\begin{array}{l}\text { - Za } 12 \text { měsíců po proběhlém } \\
\text { - premocnění } \\
\text { aneurysmata koronárních } \\
\text { tepen } \\
\text { - normální EKG } \\
\text { - normální srdeční funkce } \\
\text { - Holter: bez závažných } \\
\text { dysrytmií nebo ischemických } \\
\text { změn } \\
\text { - zátěžové vyšetření: bez } \\
\text { závažných dysrytmií nebo } \\
\text { ischemických změn } \\
\text { Doporučení: } \\
\text { - rekreační sporty podle } \\
\text { individuálních nálezů }\end{array}$ & $\begin{array}{l}\text { - velká aneurysmata } \\
\text { - porucha srdeční funkce } \\
\text { - } \text { st. p. infarktu myokardu ischemickými změnami } \\
\text { - Holter: závažné dysrytmie } \\
\text { nebo ischemické změny } \\
\text { - zátěžové vyšetřní: závažné } \\
\text { dysrytmie nebo ischemické } \\
\text { změny }\end{array}$ & $\begin{array}{l}\text { - stejně jako třída III } \\
\text { - synkopa, } \\
\text { presynkopa, } \\
\text { závažné dysrytmie } \\
\text { v anamnéze } \\
\text { - pozitivní EPS }\end{array}$ \\
\hline $\begin{array}{l}\text { Dilatační } \\
\text { kardiomyopatie }\end{array}$ & $\begin{array}{l}\text { Při prokázaném nebo } \\
\text { suspektním onemocnění, } \\
\text { nezávisle na způsobu léčby } \\
\text { Zákaz všech závodních } \\
\text { sportů }\end{array}$ & $\begin{array}{l}\text { - bez synkop nebo presynkop - } \\
\text { či závažných poruch rytmu } \\
\text { v osobní nebo rodinné } \\
\text { anamnéze } \\
\text { - mírně snížená srdeční funkce - } \\
\text { - žádná nebo středně význam- - } \\
\text { ná mitrální insuficience } \leq 2 \text {. st. } \\
\text { - Holter: bez závažných dysrytmií - } \\
\text { nebo ischemických změn } \\
\text { - zátěžové vyšetření: bez } \\
\text { závažných dysrytmií nebo } \\
\text { ischemických změn } \\
\text { Doporučení: } \\
\text { - podle individuálních nálezů } \\
\text { pouze rekreační sporty s nízkou } \\
\text { až střední tělesnou zátěží }\end{array}$ & $\begin{array}{l}\text { - bez synkop nebo presynkop } \\
\text { či závažných poruch rytmu } \\
\text { v osobní nebo rodinné } \\
\text { anamnéze } \\
\text { - středně snížená srdeční funkce } \\
\text { - významná mitrální insufi- } \\
\text { cience 3. st. } \\
\text { - Holter: bez závažných dysrytmií } \\
\text { nebo ischemických změn } \\
\text { - zátěžové vyšetření: bez } \\
\text { závažných dysrytmií nebo } \\
\text { ischemických změn } \\
\text { Doporučení: } \\
\text { - podle individuálních } \\
\text { nálezů pouze rekreační sporty } \\
\text { s nízkou tělesnou zátěží }\end{array}$ & \\
\hline
\end{tabular}


Tab. 4 Získaná a hereditární kardiovaskulární onemocnění- pokračování

\begin{tabular}{|c|c|c|c|c|}
\hline & Třída I & Třída II & Třída III & Třída IV \\
\hline Pohybová aktivita & Bez omezení & Podle tolerance & Podle tolerance & Bez větší fyz. námahy \\
\hline $\begin{array}{l}\text { Tělesná výchova } \\
\text { ve škole }\end{array}$ & Bez omezení & S úlevami & Nevhodná & Nevhodná \\
\hline Rekreační sport & Bez omezení & Možný (indiv. přístup) & S nízkou zátěží & S nízkou zátěží \\
\hline Závodní sport & Možný & Nevhodný & Zcela nevhodný & Zakázaný \\
\hline NYHA & I & II & III-IV & \\
\hline Klinické obtíže & Žádné & Mírné & Střední až významné & \\
\hline $\begin{array}{l}\text { Hemodynamické } \\
\text { projevy }\end{array}$ & Nevýznamné & Středně významné & Významné & $\begin{array}{l}\text { Vysoké riziko náhlého } \\
\text { úmrtí }\end{array}$ \\
\hline Dysrytmie & Nepřítomny/nevýznamné & Kontrolované léčbou & Závažné & \\
\hline Holter/Zátěž & $\begin{array}{l}\text { Normální/nevýznamné dysrytmie, } \\
\text { bez ischemických změn }\end{array}$ & $\begin{array}{l}\text { Normální/nevýznamné dysrytmie, } \\
\text { bez ischemických změn }\end{array}$ & $\begin{array}{l}\text { Závažné dysrytmie/ } \\
\text { ischemické změny }\end{array}$ & \\
\hline $\begin{array}{l}\text { Hypertrofická } \\
\text { kardiomyopatie }\end{array}$ & $\begin{array}{l}\text { Při prokázaném nebo suspektním } \\
\text { onemocnění, nezávisle na způsobu } \\
\text { léčby } \\
\text { Zákaz všech závodních } \\
\text { sportů }\end{array}$ & $\begin{array}{l}\text { - bez synkop nebo presynkop } \\
\text { či závažných poruch rytmu } \\
\text { v osobní nebo rodinné anamnéze } \\
\text { - normální srdeční funkce } \\
\text { - bez významné hypertrofie } \\
\text { levé komory } \\
\text { - žádná nebo nevýznamná } \\
\text { mitrální insuficience } \\
\text { - bez obstrukce výtokového } \\
\text { traktu levé komory } \\
\text { - Holter: bez závažných dysrytmií } \\
\text { nebo ischemických změn } \\
\text { - zátěžové vyšetření: bez } \\
\text { závažných dysrytmií nebo } \\
\text { ischemických změn } \\
\text { Doporučení: } \\
\text { - podle individuálních nálezů } \\
\text { pouze rekreační sporty s nízkou } \\
\text { až střední tělesnou zátěží } \\
\text { - potápění je zcela nevhodné }\end{array}$ & $\begin{array}{l}\text { - významná } \\
\text { hypertrofie } \\
\text { levé komory } \\
\text { - obstrukce výtoko- } \\
\text { vého traktu levé } \\
\text { komory } \\
\text { - mitrální insuficience } \\
\geq 2 \text {. stupně } \\
\text { Doporučení: } \\
\text { - individuální přístup } \\
\text { - zvážit primárně } \\
\text { preventivní } \\
\text { implantaci } \\
\text { ICD }\end{array}$ & $\begin{array}{l}\text { - stejně jako třída III } \\
\text { - synkopa, } \\
\text { presynkopa, závažné } \\
\text { dysrytmie v osobní } \\
\text { nebo rodinné } \\
\text { anamnéze } \\
\text { - pozitivní EPS } \\
\text { Doporučení: } \\
\text { - individuální přístup } \\
\text { - indikace k implan- } \\
\text { taci ICD }\end{array}$ \\
\hline Myokarditida & $\begin{array}{l}\text { Za } 12 \text { měsíců po proběhlém } \\
\text { onemocnění } \\
\text { - bez laboratorních známek } \\
\text { známek zánětu nebo postižení } \\
\text { myokardu } \\
\text { - ECHO: normální srdeční rozměry } \\
\text { a funkce, žádné výpotky } \\
\text { - bez závažných dysrytmií } \\
\text { - EKG: normální } \\
\text { - Holter: bez závažných dysrytmií } \\
\text { nebo ischemických změn } \\
\text { - zátěžové vyšetření: bez závažných } \\
\text { dysrytmií nebo ischemických } \\
\text { změn } \\
\text { Doporučení: } \\
\text { - závodní sporty podle individuál- } \\
\text { ních nálezů } \\
\text { - kontroly kardiologem }\end{array}$ & \multicolumn{2}{|c|}{$\begin{array}{l}\text { - reziduální nálezy } \\
\text { Doporučení: } \\
\text { - pohybová a případná rekreační sportovní aktivita } \\
\text { podle vyjádření kardiologa }\end{array}$} & $\begin{array}{l}\text { - při prokázaném } \\
\text { nebo suspektním } \\
\text { onemocnění }\end{array}$ \\
\hline Perikarditida & $\begin{array}{l}\text { - Za } 12 \text { měsíců po proběhlém } \\
\text { onemocnění } \\
\text { - bez laboratorních známek } \\
\text { známek zánětu nebo postižení } \\
\text { myokardu } \\
\text { - ECHO: normální srdeční rozměry } \\
\text { a funkce, žádné výpotky } \\
\text { - bez závažných dysrytmií } \\
\text { - EKG: normální } \\
\text { - Holter: bez závažných dysrytmií } \\
\text { nebo ischemických změn } \\
\text { - zátěžové vyšetření: bez závažných } \\
\text { dysrytmií nebo ischemických } \\
\text { změn }\end{array}$ & \multicolumn{2}{|c|}{$\begin{array}{l}\text { - reziduální nálezy } \\
\text { Doporučení: } \\
\text { - pohybová a případná rekreační sportovní aktivita } \\
\text { podle vyjádření kardiologa }\end{array}$} & $\begin{array}{l}\text { - při prokázaném } \\
\text { nebo suspektním } \\
\text { onemocnění }\end{array}$ \\
\hline
\end{tabular}


Tab. 4 Získaná a hereditární kardiovaskulární onemocnění - pokračování

\begin{tabular}{|c|c|c|c|c|}
\hline & Třída I & Trída II & Třída III & Třída IV \\
\hline $\begin{array}{l}\text { Pohybová aktivita } \\
\text { Tělesná výchova } \\
\text { ve škole }\end{array}$ & $\begin{array}{l}\text { Bez omezení } \\
\text { Bez omezení }\end{array}$ & $\begin{array}{l}\text { Podle tolerance } \\
\text { S úlevami }\end{array}$ & $\begin{array}{l}\text { Podle tolerance } \\
\text { Nevhodná }\end{array}$ & $\begin{array}{l}\text { Bez větší fyz. námahy } \\
\text { Nevhodná }\end{array}$ \\
\hline Rekreační sport & Bez omezení & Možný (indiv. přístup) & S nízkou zátěží & S nízkou zátěží \\
\hline Závodní sport & Možný & Nevhodný & Zcela nevhodný & Zakázaný \\
\hline NYHA & I & II & III-IV & \\
\hline Klinické obtíže & Žádné & Mírné & Střední až významné & \\
\hline $\begin{array}{l}\text { Hemodynamické } \\
\text { projevy }\end{array}$ & Nevýznamné & Středně významné & Významné & Vysoké riziko náhlého úmrtí \\
\hline Dysrytmie & Nepřítomny/nevýznamné & Kontrolované léčbou & Závažné & \\
\hline Holter/Zátěž & $\begin{array}{l}\text { Normální/nevýznamné } \\
\text { dysrytmie, bez ischemic- } \\
\text { kých změn }\end{array}$ & $\begin{array}{l}\text { Normální/nevýznamné } \\
\text { dysrytmie, bez ischemic- } \\
\text { kých změn }\end{array}$ & $\begin{array}{l}\text { Závažné dysrytmie/ } \\
\text { ischemické změny }\end{array}$ & \\
\hline $\begin{array}{l}\text { Marfanův } \\
\text { syndrom }\end{array}$ & Zákaz závodních sportů & $\begin{array}{l}\text { - negat. anamnéza } \\
\text { (disekce nebo náhlé } \\
\text { úmrtí u př́íbuzných) } \\
\text { - kořen aorty nebo asc. } \\
\text { aorta: } \\
\text { - adolescenti }<40 \mathrm{~mm} \\
\text { - děti }<25 \mathrm{~mm} / \mathrm{m}^{2} \\
\text { - aortální insuficience } \\
\leq 2 \text {. st. } \\
\text { - mitrální insuficience } \\
\leq 2 \text {. st. } \\
\text { Doporučení: } \\
\text { - podle individuálních } \\
\text { nálezů pouze rekreační } \\
\text { sporty s nízkou až střední } \\
\text { tělesnou zátěží } \\
\text { - rekreační sporty se } \\
\text { zvýšeným rizikem } \\
\text { závažného úrazu hrudníku } \\
\text { jsou nevhodné }\end{array}$ & $\begin{array}{l}\text { - kořen aorty nebo asc. } \\
\text { aorta: } \\
\text { adolescenti }>40 \mathrm{~mm} \\
\text { děti }>25 \mathrm{~mm} / \mathrm{m}^{2} \\
\text { - aortální insuficience } \\
\text { > 2. st. } \\
\text { - mitrální insuficience } \\
\text { > 2. st. } \\
\text { Doporučení: } \\
\text { - zvážit indikaci } \\
\text { k chirurgické léčbě } \\
\text { - podle individuálních } \\
\text { nálezů pouze rekreační } \\
\text { sporty s nízkou tělesnou } \\
\text { zátěží } \\
\text { - rekreační sporty se } \\
\text { zvýšeným rizikem } \\
\text { závažného úrazu hrudníku } \\
\text { jsou zcela nevhodné }\end{array}$ & $\begin{array}{l}\text { - stejně jako třída III } \\
\text { - disekce nebo náhlé úmrtí } \\
\text { - vysoké riziko ruptury } \\
\text { aorty při úrazech } \\
\text { hrudníku } \\
\text { Doporučení: } \\
\text { - zvážit indikaci } \\
\text { k chirurgické léčbě } \\
\text { - potápění je zcela } \\
\text { nevhodné } \\
\text { - pohybová a případná } \\
\text { rekreační sportovní aktivita } \\
\text { podle vyjádření kardiologa }\end{array}$ \\
\hline $\begin{array}{l}\text { Arytmogenní } \\
\text { kardiomyopatie } \\
\text { pravé komory }\end{array}$ & $\begin{array}{l}\text { Při prokázaném nebo } \\
\text { suspektním onemocnění, } \\
\text { nezávisle na způsobu léčby } \\
\text { Zákaz všech závodních } \\
\text { sportů }\end{array}$ & & & $\begin{array}{l}\text { Doporučení: } \\
\text { - pohybová a případná } \\
\text { rekreační sportovní } \\
\text { aktivita podle vyjádření } \\
\text { arytmologa } \\
\text { - potápění zcela } \\
\text { nevhodné }\end{array}$ \\
\hline
\end{tabular}

Tab. 5 Poruchy srdečního rytmu

\begin{tabular}{|c|c|c|c|c|}
\hline & Třída I & Trída II & Třída III & Trída IV \\
\hline Pohybová aktivita & Bez omezení & Podle tolerance & Podle tolerance & Bez větší fyz. námahy \\
\hline $\begin{array}{l}\text { Tělesná výchova } \\
\text { ve škole }\end{array}$ & Bez omezení & S úlevami & Nevhodná & Nevhodná \\
\hline Rekreační sport & Bez omezení & Možný (indiv. přístup) & S nízkou zátěží & S nízkou zátěží \\
\hline Závodní sport & Možný & Nevhodný & Zcela nevhodný & Zakázaný \\
\hline Dysrytmie & $\begin{array}{l}\text { Nevýznamné nebo } \\
\text { kontrolované léčbou }\end{array}$ & Kontrolované léčbou & $\begin{array}{l}\text { Závažné nebo nedostatečně } \\
\text { kontrolované léčbou }\end{array}$ & $\begin{array}{l}\text { Vysoké riziko náhlého } \\
\text { úmrtí }\end{array}$ \\
\hline $\begin{array}{l}\text { Dysfunkce sinusového } \\
\text { uzlu }\end{array}$ & $\begin{array}{l}\text { Strukturálně normální srdce } \\
\text { - Holter bez } \\
\text { významnějších pauz } \\
\text { - přiměřená tepová } \\
\text { akcelerace při zátěžovém } \\
\text { vyšetření }\end{array}$ & \multicolumn{3}{|c|}{$\begin{array}{l}\text { - strukturální srdeční onemocnění (omezení podle základní } \\
\text { - víznózyamnější dysfunkce sinusového uzlu } \\
\text { - synkopy nebo presynkopy } \\
\text { Doporučení: } \\
\text { - při synkopách nebo presynkopách zákaz rekreačních sportů, } \\
\text { u kterých i krátká ztráta vědomí může ohrozit pacienta nebo } \\
\text { jeho okolí } \\
\text { - zvážit implantaci kardiostimulátoru } \\
\text { - pohybová a případná rekreační sportovní aktivita } \\
\text { podle vyjádření kardiologa }\end{array}$} \\
\hline
\end{tabular}


Tab. 5 Poruchy srdečního rytmu - pokračování

\begin{tabular}{|c|c|c|c|c|}
\hline & Trída I & Třída II & Třída III & Trída IV \\
\hline Pohybová aktivita & Bez omezení & Podle tolerance & Podle tolerance & Bez větší fyz. námahy \\
\hline $\begin{array}{l}\text { Tělesná výchova } \\
\text { ve škole }\end{array}$ & Bez omezení & S úlevami & Nevhodná & Nevhodná \\
\hline Rekreační sport & Bez omezení & Možný (indiv. přístup) & S nízkou zátěží & S nízkou zátěží \\
\hline Závodní sport & Možný & Nevhodný & Zcela nevhodný & Zakázaný \\
\hline Dysrytmie & $\begin{array}{l}\text { Nevýznamné nebo } \\
\text { kontrolované léčbou }\end{array}$ & Kontrolované léčbou & $\begin{array}{l}\text { Závažné nebo nedostatečně } \\
\text { kontrolované léčbou }\end{array}$ & $\begin{array}{l}\text { Vysoké riziko náhlého } \\
\text { úmrtí }\end{array}$ \\
\hline $\begin{array}{l}\text { Atrioventrikulární } \\
\text { blokáda I. st. }\end{array}$ & $\begin{array}{l}\text { Strukturálně normální srdce } \\
\text { - Holter bez } \\
\text { významnějších pauz } \\
\text { - přiměřená tepová } \\
\text { akcelerace při zátěžovém } \\
\text { vyšetření }\end{array}$ & $\begin{array}{l}\text { - strukturální srdeční or } \\
\text { základní diagnózy) } \\
\text { Doporučení: } \\
\text { - pohybová a případná } \\
\text { kardiologa }\end{array}$ & $\begin{array}{l}\text { ocnění (omezení podle } \\
\text { rtovní aktivita podle vyjádření }\end{array}$ & \\
\hline $\begin{array}{l}\text { Atrioventrikulární } \\
\text { blokáda II. st. 1. typ }\end{array}$ & $\begin{array}{l}\text { Strukturálně normální srdce } \\
\text { - Holter bez } \\
\text { významnějších pauz } \\
\text { - přiměřená tepová } \\
\text { akcelerace při zátěžovém } \\
\text { vyšetření }\end{array}$ & $\begin{array}{l}\text { - strukturální srdeční o } \\
\text { základní diagnózy) } \\
\text { - významnější blokáda } \\
\text { Doporučení: } \\
\text { - zvážit implantaci kard } \\
\text { - pohybová a případná } \\
\text { podle vyjádření kardi }\end{array}$ & $\begin{array}{l}\text { ocnění (omezení podle } \\
\text { imulátoru } \\
\text { eační sportovní aktivita } \\
\text { a }\end{array}$ & \\
\hline $\begin{array}{l}\text { Atrioventrikulární } \\
\text { blokáda II. st. 2. typ }\end{array}$ & \multicolumn{4}{|c|}{ - stejně jako získaná AV blokáda III. st } \\
\hline $\begin{array}{l}\text { Vrozená } \\
\text { atrioventrikulární } \\
\text { blokáda III. st. }\end{array}$ & $\begin{array}{l}\text { Strukturálně normální srdce } \\
\text { - bez synkop nebo } \\
\text { presynkop v anamnéze } \\
\text { - normální srdeční funkce } \\
\text { - klidová srdeční } \\
\text { frekvence > 50/min } \\
\text { s přiměřenou akcelerací } \\
\text { při zátěži } \\
\text { - normální šíře QRS } \\
\text { - žádné nebo sporadické } \\
\text { komorové extrasystoly } \\
\text { při zátěži } \\
\text { Doporučení: } \\
\text { - sporty s vysokou } \\
\text { statickou nebo } \\
\text { dynamickou zátěží } \\
\text { jsou nevhodné }\end{array}$ & $\begin{array}{l}\text { - strukturální srdeční or } \\
\text { základní diagnózy) } \\
\text { - porucha srdeční funk } \\
\text { - významnější blokáda } \\
\text { Doporučení: } \\
\text { - zvážit implantaci kard } \\
\text { - pohybová a případná } \\
\text { podle vyjádření arytm }\end{array}$ & $\begin{array}{l}\text { ocnění (omezení podle } \\
\text { imulátoru } \\
\text { eační sportovní aktivita } \\
\text { ga }\end{array}$ & $\begin{array}{l}\text { - synkopy nebo } \\
\text { presynkopy } \\
\text { Doporučení: } \\
\text { - indikace k implantaci } \\
\text { kardiostimulátoru }\end{array}$ \\
\hline $\begin{array}{l}\text { Získaná atrioventrikulární } \\
\text { blokáda III. st. }\end{array}$ & \multicolumn{4}{|c|}{$\begin{array}{l}\text { Doporučení: } \\
\text { - implantace kardiostimulátoru } \\
\text { - pohybová a prípadná rekreační sportovní aktivita podle vyjádření arytmologa }\end{array}$} \\
\hline Síňové extrasystoly & \multicolumn{4}{|l|}{$\begin{array}{l}\text { Strukturálně normální srdce } \\
\text { - normální Holter } \\
\text { a zátěžové vyšetření }\end{array}$} \\
\hline $\begin{array}{l}\text { Flutter síní } \\
\text { (bez preexcitace) }\end{array}$ & $\begin{array}{l}\text { Strukturálně normální srdce } \\
\text { Za } 1 \text { měsíc po úspěšné } \\
\text { ablaci: } \\
\text { - přiměřená tepová } \\
\text { frekvence v klidu a při } \\
\text { zátěžovém vyšetření } \\
\text { Doporučení: } \\
\text { - sport podle vyjádření } \\
\text { arytmologa }\end{array}$ & $\begin{array}{l}\text { - kontrolovaný léčbou } \\
\text { - strukturální srdeční or } \\
\text { diagnózy) } \\
\text { Doporučení: } \\
\text { - zvážit intervenci } \\
\text { - pohybová a případná } \\
\text { vyjádření arytmologa }\end{array}$ & $\begin{array}{l}\text { ocnění (omezení podle základní } \\
\text { eační sportovní aktivita podle }\end{array}$ & $\begin{array}{l}\text { - synkopy nebo } \\
\text { presynkopy } \\
\text { - neúčinná léčba } \\
\text { Doporučení: } \\
\text { - indikace k intervenci }\end{array}$ \\
\hline $\begin{array}{l}\text { Fibrilace síní } \\
\text { (bez preexcitace) }\end{array}$ & $\begin{array}{l}\text { Strukturálně normální srdce } \\
\text { Za } 1 \text { měsíc po úspěšné ablaci: } \\
\text { - přiměřená tepová } \\
\text { frekvence v klidu a při } \\
\text { zátěžovém vyšetření } \\
\text { Doporučení: } \\
\text { - sport podle vyjádření } \\
\text { arytmologa }\end{array}$ & $\begin{array}{l}\text { - kontrolovaná léčbou } \\
\text { - strukturální srdeční or } \\
\text { diagnózy) } \\
\text { Doporučení: } \\
\text { - zvážit intervenci } \\
\text { - pohybová a případná } \\
\text { vyjádření arytmologa }\end{array}$ & $\begin{array}{l}\text { ocnění (omezení podle základní } \\
\text { eační sportovní aktivita podle }\end{array}$ & \\
\hline
\end{tabular}


Tab. 5 Poruchy srdečního rytmu - pokračování

\begin{tabular}{|c|c|c|c|c|}
\hline & Třída I & Třída II & Třída III & Třída IV \\
\hline $\begin{array}{l}\text { Pohybová aktivita } \\
\text { Tělesná výchova } \\
\text { ve škole }\end{array}$ & $\begin{array}{l}\text { Bez omezení } \\
\text { Bez omezení }\end{array}$ & $\begin{array}{l}\text { Podle tolerance } \\
\text { S úlevami }\end{array}$ & $\begin{array}{l}\text { Podle tolerance } \\
\text { Nevhodná }\end{array}$ & $\begin{array}{l}\text { Bez větší fyz. námahy } \\
\text { Nevhodná }\end{array}$ \\
\hline Rekreační sport & Bez omezení & Možný (indiv. přístup) & S nízkou zátěží & S nízkou zátěží \\
\hline Závodní sport & Možný & Nevhodný & Zcela nevhodný & Zakázaný \\
\hline Dysrytmie & $\begin{array}{l}\text { Nevýznamné nebo } \\
\text { kontrolované léčbou }\end{array}$ & Kontrolované léčbou & $\begin{array}{l}\text { Závažné nebo nedostatečně } \\
\text { kontrolované léčbou }\end{array}$ & $\begin{array}{l}\text { Vysoké riziko náhlého } \\
\text { úmrtí }\end{array}$ \\
\hline $\begin{array}{l}\text { Síňová ektopická } \\
\text { tachykardie } \\
\text { (bez preexcitace) }\end{array}$ & $\begin{array}{l}\text { Strukturálně normální srdce } \\
\text { Za } 1 \text { měsíc po úspěšné } \\
\text { ablaci: } \\
\text { - přiměřená tepová } \\
\text { frekvence v klidu a při } \\
\text { zátěžovém vyšetření } \\
\text { Doporučení: } \\
\text { - sport podle vyjádření } \\
\text { kardiologa }\end{array}$ & \multicolumn{2}{|c|}{$\begin{array}{l}\text { - kontrolovaná léčbou } \\
\text { - strukturální srdeční onemocnění (omezení podle základní } \\
\text { diagnózy) } \\
\text { Doporučení: } \\
\text { - pohybová a případná rekreační sportovní aktivita podle } \\
\text { vyjádření kardiologa }\end{array}$} & \\
\hline $\begin{array}{l}\text { Uniklé nebo předčasné } \\
\text { junkční stahy }\end{array}$ & $\begin{array}{l}\text { Strukturálně normální srdce } \\
\text { - normální Holter } \\
\text { a zátěžové vyšetření } \\
\text { bez vzniku setrvalé } \\
\text { tachykardie }\end{array}$ & \multicolumn{2}{|c|}{$\begin{array}{l}\text { - strukturální srdeční onemocnění (omezení podle základní } \\
\text { diagnózy) } \\
\text { Doporučení: } \\
\text { - pohybová a prípadná rekreační sportovní aktivita podle } \\
\text { vyjádření kardiologa }\end{array}$} & \\
\hline $\begin{array}{l}\text { Junkční ektopická } \\
\text { tachykardie }\end{array}$ & $\begin{array}{l}\text { Strukturálně normální srdce } \\
\text { - přiměřená tepová } \\
\text { frekvence v klidu a při } \\
\text { zátěžovém vyšetření } \\
\text { Doporučení: } \\
\text { - sport podle vyjádření } \\
\text { kardiologa }\end{array}$ & \multicolumn{2}{|c|}{$\begin{array}{l}\text { - kontrolovaná léčbou } \\
\text { - strukturální srdeční onemocnění (omezení podle základní } \\
\text { diagnózy) } \\
\text { Doporučení: } \\
\text { - pohybová a případná rekreační sportovní aktivita podle } \\
\text { vyjádření kardiologa }\end{array}$} & \\
\hline $\begin{array}{l}\text { Supraventrikulární } \\
\text { reentry tachykardie } \\
\text { nodální nebo } \\
\text { skrytá spojka } \\
\text { (pouze } \\
\text { s retrográdním } \\
\text { vedením) }\end{array}$ & $\begin{array}{l}\text { Strukturálně normální srdce } \\
\text { - sporadické ataky } \\
\text { tachykardie, které } \\
\text { nejsou indukované } \\
\text { zátěží } \\
\text { Za } 1 \text { měsíc po úspěšné } \\
\text { ablaci } \\
\text { Doporučení: } \\
\text { - sport podle vyjádření } \\
\text { kardiologa }\end{array}$ & \multicolumn{2}{|c|}{$\begin{array}{l}\text { - kontrolovaná léčbou } \\
\text { - strukturální srdeční onemocnění (omezení podle základní } \\
\text { diagnózy) } \\
\text { Doporučení: } \\
\text { - zvážit katetrizační ablaci } \\
\text { - pohybová a případná rekreační sportovní aktivita podle } \\
\text { vyjádření kardiologa }\end{array}$} & $\begin{array}{l}\text { - synkopy nebo } \\
\text { presynkopy } \\
\text { - neúčinná léčba } \\
\text { Doporučení: } \\
\text { - indikace katetrizační } \\
\text { ablace }\end{array}$ \\
\hline Syndrom WPW & $\begin{array}{l}\text { Stejné jako u supraventriku- } \\
\text { lární reentry tachykardie + } \\
\text { - náhlé a jasné vymizení } \\
\text { preexcitace při zátěžo- } \\
\text { vém vyšetření nebo } \\
\text { - nejkratší preexcitovaný } \\
\text { RR interval při indukova- } \\
\text { né fibrilaci síní } \geq 250 \text { ms } \\
\text { Za } 1 \text { měsíc po úspěšné } \\
\text { ablaci } \\
\text { Doporučení: } \\
\text { - sport podle vyjádření } \\
\text { arytmologa }\end{array}$ & \multicolumn{2}{|c|}{$\begin{array}{l}\text { - kontrolovaná léčbou } \\
\text { - diagnózy) } \\
\text { - antegrádní refrakterní perioda přídatné spojky < } 250 \text { ms } \\
\text { Doporučení: } \\
\text { - zvážit katetrizační ablaci } \\
\text { - pohybová a prípadná rekreační sportovní aktivita podle } \\
\text { vyjádření arytmologa }\end{array}$} & $\begin{array}{l}\text { - synkopy, presynkopy } \\
\text { - fibrilace nebo flutter } \\
\text { síní } \\
\text { - neúspěšná léčba } \\
\text { Doporučení: } \\
\text { - absolutní indikace } \\
\text { katetrizační ablace }\end{array}$ \\
\hline $\begin{array}{l}\text { Komorové } \\
\text { extrasystoly }\end{array}$ & $\begin{array}{l}\text { Strukturálně normální srdce } \\
\text { - monomorfní extrasy- } \\
\text { stoly } \\
\text { - bez progrese četnosti } \\
\text { při zátěžovém vyšetření } \\
\text { nebo při Holteru } \\
\text { - bez průkazu gene- } \\
\text { tického arytmického } \\
\text { syndromu } \\
\text { Doporučení: } \\
\text { - kontroly kardiologem }\end{array}$ & $\begin{array}{l}\text { - strukturálně normální } \\
\text { - proge } \\
\text { nebo při Holteru } \\
\text { Doporučení: } \\
\text { - pohybová a případná } \\
\text { rekreační sportovní } \\
\text { aktivita podle vyjádření } \\
\text { arytmologa }\end{array}$ & $\begin{array}{l}\text { - strukturální srdeční } \\
\text { onemocnění s rizikovými } \\
\text { faktory (omezení podle } \\
\text { základní diagnózy) } \\
\text { Doporučení: } \\
\text { - zvážit intervenci nebo } \\
\text { reintervenci }\end{array}$ & $\begin{array}{l}\text { - stejně jako třída III } \\
\text { - synkopy, presynkopy } \\
\text { - komorová tachykardie } \\
\text { Doporučení: } \\
\text { - zvážit intervenci nebo } \\
\text { reintervenci }\end{array}$ \\
\hline
\end{tabular}


Tab. 5 Poruchy srdečního rytmu - pokračování

\begin{tabular}{|c|c|c|c|c|}
\hline & Třída I & Třída II & Třída III & Třída IV \\
\hline Pohybová aktivita & Bez omezení & Podle tolerance & Podle tolerance & Bez větší fyz. námahy \\
\hline $\begin{array}{l}\text { Tělesná výchova } \\
\text { ve škole }\end{array}$ & Bez omezení & S úlevami & Nevhodná & Nevhodná \\
\hline Rekreační sport & Bez omezení & Možný (indiv. přístup) & S nízkou zátěží & S nízkou zátěží \\
\hline Závodní sport & Možný & Nevhodný & Zcela nevhodný & Zakázaný \\
\hline Dysrytmie & $\begin{array}{l}\text { Nevýznamné nebo } \\
\text { kontrolované léčbou }\end{array}$ & Kontrolované léčbou & $\begin{array}{l}\text { Závažné nebo nedostatečně } \\
\text { kontrolované léčbou }\end{array}$ & $\begin{array}{l}\text { Vysoké riziko náhlého } \\
\text { úmrtí }\end{array}$ \\
\hline Komorová tachykardie & $\begin{array}{l}\text { Při prokázaném nebo } \\
\text { suspektním onemocnění, } \\
\text { nezávisle na způsobu léčby } \\
\text { Zákaz všech závodních } \\
\text { sportů }\end{array}$ & & & $\begin{array}{l}\text { Doporučení: } \\
\text { - pohybová a případná } \\
\text { rekreační sportovní } \\
\text { aktivita podle vyjádření } \\
\text { arytmologa } \\
\text { - potápění zcela } \\
\text { nevhodné }\end{array}$ \\
\hline $\begin{array}{l}\text { Syndrom dlouhého QT } \\
\text { intervalu }\end{array}$ & $\begin{array}{l}\text { Při prokázaném nebo } \\
\text { suspektním onemocnění, } \\
\text { nezávisle na způsobu léčby } \\
\text { Zákaz všech závodních } \\
\text { sportů }\end{array}$ & & & $\begin{array}{l}\text { Doporučení: } \\
\text { - pohybová a případná } \\
\text { rekreační sportovní } \\
\text { aktivita podle vyjádření } \\
\text { arytmologa } \\
\text { - potápění zcela } \\
\text { nevhodné }\end{array}$ \\
\hline $\begin{array}{l}\text { Katecholaminogenní } \\
\text { polymorfní komorová } \\
\text { tachykardie }\end{array}$ & $\begin{array}{l}\text { Při prokázaném nebo } \\
\text { suspektním onemocnění, } \\
\text { nezávisle na způsobu léčby } \\
\text { Zákaz všech závodních } \\
\text { sportů }\end{array}$ & & & $\begin{array}{l}\text { Doporučení: } \\
\text { - pohybová a případná } \\
\text { rekreační sportovní } \\
\text { aktivita podle vyjádření } \\
\text { arytmologa } \\
\text { - potápění zcela } \\
\text { nevhodné }\end{array}$ \\
\hline Syndrom Brugadových & $\begin{array}{l}\text { Při prokázaném nebo } \\
\text { suspektním onemocnění, } \\
\text { nezávisle na způsobu léčby } \\
\text { Zákaz všech závodních } \\
\text { sportů }\end{array}$ & & & $\begin{array}{l}\text { Doporučení: } \\
\text { - pohybová a případná } \\
\text { rekreační sportovní } \\
\text { aktivita podle vyjádření } \\
\text { arytmologa } \\
\text { - potápění zcela } \\
\text { nevhodné }\end{array}$ \\
\hline Kardiostimulátor ICD & & & & $\begin{array}{l}\text { Doporučení: } \\
\text { - podle vyjádření } \\
\quad \text { arytmologa }\end{array}$ \\
\hline \multicolumn{5}{|c|}{$\begin{array}{l}\text { Zkratky: EPS - elektrofyziologická studie; ICD - implantabilní kardioverter-defibrilátor; intervence (int.) - operace, nebo terapeutická katetrizace; LV - levá } \\
\text { komora, MVP - prolaps mitrální chlopně; reintervence - opakovaný léčebný zákrok; } \mathrm{SpO}_{2} \text { - pulsní oxymetrie, WPW - Wolffův-Parkinsonův-Whiteův syndrov }\end{array}$} \\
\hline \multicolumn{5}{|c|}{$\begin{array}{l}\text { Kontaktní sporty nebo sporty se zvýšeným rizikem úrazu jsou nevhodné u jedinců: } \\
\text { - s kardiostimulátorem } \\
\text { - s kardioverterem-defibrilátorem } \\
\text { - s umělou chlopní } \\
\text { - s konduitem } \\
\text { - s antikoagulační léčbou } \\
\text { - s kořenem aorty nebo } \mathrm{s} \text { asc. aortou }>40 \mathrm{~mm}\left(21 \mathrm{~mm} / \mathrm{m}^{2}\right)\end{array}$} \\
\hline
\end{tabular}

znamnosti klinických obtíží, hemodynamických projevů, anamnestických nebo současných poruch srdečního rytmu, výsledků Holterovy monitorace a zátěžového vyšetření rozlišujeme čtyři třídy s rozdílným doporučením k pohybové aktivitě, školní tělesné výchově a rekreačnímu či závodnímu sportování. Hlavním cílem byla snaha definovat podmínky pro zařazení do trrídy I, ve které nejsou zásadní omezení ani pro závodní sport, a naopak charakterizovat onemocnění, která ohrožují pacienta náhlým úmrtím při zvýšené tělesné aktivitě spadajících do třídy IV. Projevy kardiovaskulárních onemocnění ve třídách II a III se vzájemně mohou překrývat. Pro vrozené srdeční vady, které v tabulce 3 nejsou uvedeny, jsou použita doporučení pro morfologicky a funkčně podobná onemocnění.

Tělesná výchova ve škole s úlevami může být do jisté míry problematická, protože pod termínem úlevy si každý učitel může představovat něco jiného. Je odpovědností rodičů, aby informovali pedagogický personál o podstatě onemocnění dítěte a o možných nežádoucích projevech. Obecně lze doporučit, aby jedinci ve třídě II nebyli při tělesné výchově klasifikováni a aby po nich nebyly vyžadovány časově limitované výkony, jako je sprint, vytrvalostní běh apod. Nevhodné mohou být také $\mathrm{v}$ některých případech šplh a cviky na nářadí ve výšce pro riziko pádu při dočasné indispozici. Některá kardiovaskulární onemocnění mají svá 
specifika, napřr. u jedinců po úplném kavopulmonálním spojení je jistě nežádoucí vis vzhůru nohama například na kruzích nebo hrazdě. Sporty se zvýšeným rizikem úrazu, např. kontaktní sporty, skoky do vody, box, bojové sporty, horolezectví apod. (viz tabulku 1), jsou nevhodné u pacientů s konduity, s umělou chlopní, s kardiostimulátorem a při antikoagulační léčbě. U jedinců s kardiostimulátorem nebo s kardioverterem-defibrilátorem se řídíme doporučením arytmologa.

Zvláštní pozornost vyžadují jedinci ve třídě IV, zejména $\mathrm{v}$ případě geneticky podmíněných kardiovaskulárních onemocnění s vysokým rizikem náhlého úmrtí. Ve škole jsou osvobozeni od tělesné výchovy. Rekreační pohybová aktivita s mírnou fyzickou zátěží je možná, např. rychlá chůze nebo golf. Při fyzické aktivitě je vhodné se vyvarovat náhlé zátěže, extrémně horkému nebo studenému prostředí a náhlému stresu, které zvyšují adrenergní aktivitu. Důležité je ukončení činnosti při počínajících obtížích, jako jsou točení hlavy, mžitky před očima, palpitace, nepravidelný puls a bolesti na hrudníku. Plavání je zvažováno individuálně podle základního onemocnění (např. je nevhodné u syndromu dlouhého QT intervalu) a vždy pod dohledem pro riziko utonutí. Potápění je ve tř́idě IV zcela nevhodné.

\section{Závěr}

Doporučení pro pohybovou aktivitu a sportování u dětí a mladistvých s kardiovaskulárním onemocněním nejsou a ani nemohou být rigidní a závazná. Každý případ je posuzován individuálně podle základní diagnózy, podrobné anamnézy a objektivních vyšetřovacích metod. Tabelární uspořádání podle základní diagnózy a omezení sportovních a pohybových aktivit usnadní orientaci dětských kardiologů, praktických dětských lékařů a tělovýchovných lékařů v této problematice. V souhrnu lze říci, že jak nadměrná ochrana před pohybovou aktivitou a sportem u nevýznamných onemocnění nebo po úspěšných intervenčních zákrocích, tak bagatelizace nálezů a závodní sport u závažných onemocnění jsou chybné.

\section{Literatura}

1. Pina IL, Apstein CS, Balady GJ, Belardinelli R, et al. Exercise and heart failure: a statement from the American Heart Association Committee on exercise, rehabilitation, and prevention. Circulation 2003;107:1210-1225.

2. Maron BJ, Zipes DP. $36^{\text {th }}$ Bethesda Conference: Eligibility recommendations for competitive athletes with cardiovascular abnormalities. J Am Coll Cardiol 2005;45:1313-1375.

3. Pelliccia A, Zipes DP, Maron BJ. Bethesda Conference \#36 and the European Society of Cardiology Consensus Recommendations revisited a comparison of U.S. and European criteria for eligibility and disqualification of competitive athletes with cardiovascular abnormalities. J Am Coll Cardiol 2008;52:1990-1996.

4. Pelliccia A, Fagard R, Bjornstad HH, et al. Recommendations for competitive sports participation in athletes with cardiovascular disease: a consensus document from the Study Group of Sports Cardiology of the Working Group of Cardiac Rehabilitation and Exercise Physiology and the Working Group of Myocardial and Pericardial Diseases of the European Society of Cardiology. Eur Heart J 2005;26:1422-1445.

5. Maron BJ, Chaitman BR, Ackerman MJ, et al. Recommendations for physical activity and recreational sports participation for young patients with genetic cardiovascular diseases. Circulation 2004;109:2807-2816.

6. Pelliccia A, Corrado D, Bjornstad HH, et al. Recommendations for participation in competitive sport and leisure-time physical activity in individuals with cardiomyopathies, myocarditis and pericarditis. Eur J Cardiovasc Prev Rehabil 2006;13:876-885.

7. Šamánek M, Urbanová Z, Reich O, et al. Doporučení pro diagnostiku a léčbu hypertenze v dětství a dospívání. Cor Vasa 2009;51:227-235. 